\title{
Credit scores and the performance of newly-listed stocks: An exploration of the Chinese A-share market
}

\author{
Charlie X. Cai ${ }^{(a)}$ \\ University of Liverpool \\ Paul B. McGuinness ${ }^{(b, *)}$ \\ The Chinese University of Hong Kong \\ Qi Zhang ${ }^{(\mathrm{c})}$ \\ Durham University
}

a Professor of Finance, University of Liverpool Management School, Liverpool, UK.

Email: X.Cai7@liverpool.ac.uk

Professor, Department of Finance, CUHK Business School, Cheng Yu Tung Building, The Chinese University of Hong Kong, Sha Tin, N. T., Hong Kong.

Email: mcguinne@,baf.cuhk.edu.hk.

Reader in Accounting and Finance, Durham University Business School, Durham, UK. Email: qi.zhang2@,durham.ac.uk.

* Corresponding Author: Paul B. McGuinness.

Draft dated: 9 August 2017

\section{Acknowledgements:}

We thank S\&P Global Market Intelligence for the provision of Credit Model (CM) scores necessary for the completion of this study. This project developed from a request by S\&P in February 2014 to assess the power of CM scores in explaining post-IPO performance. Our investigation offers a framework for assessing this question as well as other related themes. We especially thank Clemens Thym, Michelle P. Cheong and Phillip Lee of S\&P Global Market Intelligence for earlier discussions, suggestions and input. Additionally, we express thanks to Daniel Chan and Jack Wong.

We also thank an anonymous reviewer for comments rendered on an earlier draft of this paper. 


\title{
Credit Scores and the performance of newly-listed stocks: An exploration of the Chinese A-share market
}

\begin{abstract}
This study assesses the power of S\&P Global Market Intelligence's CreditModel (CM) scores in explaining the short- and long-run performance of newly-listed Chinese firms. A unique feature of the data arises from such scores being outside the public domain during the study period. Focus on such a period avoids the signalling and self-selection biases that inevitably plague studies delving into the relevance of publicly-announced credit ratings. $\left[{ }^{*}\right]$ We find that $\mathrm{CM}$ scores exhibit positive association with post-listing buy-and-hold stock returns. Even stronger associations emerge when considering fundamental accounting performance, especially over longer-run horizons. In respect of the listing of Chinese Ashare firms, we conjecture that greater alignment between secondary market prices and fundamentals would likely have arisen had such scores been in the public domain during the study period.
\end{abstract}

Keywords: Credit Score, IPO Pricing, Post IPO Performance

JEL: G24, G31

[*] As an important upfront qualification, we remind readers that the present study's data focus is on S\&P Global Market Intelligence's CreditModel scores. Consequently, our study does not examine formal credit ratings. Note 1 offers further and important specific detail on this point. 


\section{Introduction}

This study investigates the extent to which S\&P Global Market Intelligence’s CreditModel $(\mathrm{CM})^{1}$ scores explain short- and long-run post-IPO performance in newly-listed Chinese firms. We examine both IPO stock and fundamental (accounting) returns for firms listing on the Shanghai and Shenzhen stock exchange markets.

A sizeable body of work documents a link between the public disclosure of credit ratings and the pricing of new equity issues. This literature covers both initial public offerings (IPOs) and follow-on seasoned equity offers (SEOs). Highlights in this field include Liu and Malatesta (2005), An and Chan (2008), Poon and Chan (2008), Poon et al. (2013) and Gounopoulos et al. (2013). This literature's central theme concerns the role of formal credit rating disclosures in squeezing information asymmetries. The studies generally find lower ex-ante uncertainty and underpricing levels in issuers possessing formal credit rating at IPO (see, most especially, An and Chan, 2008 for the US; and Poon et al., 2012 for China).

In relation to China, findings are limited by the general absence of formal credit-ratings ${ }^{2}$ on IPO firms. ${ }^{3}$ This fact affords computed CM scores, as backdated to the point of IPO in the majority of recent A-share offerings, even greater potential information value. ${ }^{4}$ Unlike India, where a regime of enforced "IPO Grading" (Deb and Marisetty, 2010; and Jacob and Agarwalla, 2012) exists, investors in the Chinese A-share IPO market are largely deprived of credit evaluation information.

Our investigation of the information content of credit scores offers two important advantages relative to existing studies. First, an important and acknowledged deficiency of

1. For background on these recently developed scores, see the following web links:

https://www.spcapitaliq.com/ \& https://www.spcapitaliq.com/documents/products/CreditModel v2.pdf.

Moreover, S\&P stipulates (in verbatim) that,

"S\&P Global Ratings does not contribute to or participate in the creation of CreditModel Scores generated by S\&P Global Market Intelligence. Lowercase nomenclature is used to differentiate S\&P Global Market Intelligence's Credit Model scores from the credit ratings issued by S\&P Global Ratings."

2. Gounopoulos et al. (2013: p. 22) report that as of the IPO launch in their study sample, only 131 of 2,096 firms listing over the period 1990-2011 possessed formal credit-ratings (= 6.25 percent of available A-listing firms).

3. Reference to Table 1 (Page 22) in Gounopoulos et al. (2013) reveals that the proportion of IPO issuers with formal credit rating dropped markedly from 2004. This coincides with the emergence of the Shenzhen Stock Exchange SME market, and a flow of smaller, unrated IPOs post-2004. The 2009 opening of the Shenzhen Stock Exchange's ChiNext board reinforced this trend. CM scores should offer even greater guidance on fundamental value in an environment where formal credit ratings are all but absent.

4. The data capture CM scores at the point of listing. A CM score is a composite measure determined by S\&P in relation to a listing firm's financials for the 12 -month period prior to listing. S\&P informs us that the backdated Chinese A-listed issuer CM scores were only accessible to public users from April 2013. Given our 2009-12 IPO sample-frame, CM scores lay outside the public domain during the initial and early post-listing period for all issuers in our sample-frame. 
studies investigating the impact of formal credit ratings on stock pricing is the potential for signalling effects. The disclosure act itself, as well as the quality of rating granted, impacts on initial and subsequent stock returns. Analysts and value traders may be guided by such rating signals (Cheng and Subramanyam, 2008). ${ }^{5}$ The absence of a rating might also limit asset managers' choices and even curb analyst recommendations. By utilizing back-dated CM scores, the present study conveniently sidesteps such signalling concerns. To emphasize, such backdated scores were not in the public domain during the IPO seasoning period for our sample firms.

Second, self-selection bias adds a further layer of complexity when assessing the real explanatory power of publicly-disclosed credit ratings. Prior firm performance dictates whether or not a formal credit rating is granted. The fact that many ratings are "solicited" compounds this potential issue (Bannier et al., 2010). Byoun et al. (2014) demonstrate that "solicited" ratings reflect a mix of insider and public information, while unsolicited ratings largely exclude insider information. They ascribe the differential in the two groups' post-rating performance to issues of self-selection rather than any bias in an agency's unsolicited evaluations. In contrast to "solicited" ratings, CM scores in our database are not fee dependent. An entity's backdated CM score is thus readily available no matter the level of prior-year firm performance. The principal requirement for an unqualified score is a complete set of financial accounts pre-IPO.

As CM scores were not in the public domain until some considerable time after IPO completion, the present study offers a much clearer view of the real effects of a firm's credit condition on its post-listing performance. Study of CM scores thus avoids biases and contaminating effects resulting from both signalling and self-selection issues. Moreover, adjustments offered in the literature for self-selection serve at best as highly imperfect remedies.

Our general findings suggest that awareness of CM scores helps deepen understanding of the post-IPO performance of newly-listed Chinese A- share firms. CM scores exhibit positive association with post-IPO buy-and-hold stock returns. Even stronger associations exist when considering fundamental accounting performance. We examine such associations for the first 12 quarters (36 months) of listing. Return-on-assets (ROA) and return-on-equity (ROE) measures both increase monotonically with CM quality. Moreover, the associations grow statistically stronger with the length of post-listing time horizon considered. CM scores thus strongly anticipate a listed entity's medium- to longer-run performance. ${ }^{6}$

5. Cheng and Subramanyam (2008) demonstrate that a firm's default risk is decreasing in the number of analysts it attracts. Mansi et al. (2011, p. 129) observe that lower bond ratings correspond to greater dispersion in analyst forecasts on issuer prospects.

${ }^{6}$. We also extend analysis of financial accounting data, as reflected in a composite CM score, to a primary-market setting devoid of credit ratings. Findings thus go beyond analysis of how accounting information explains credit rating levels (see Doumpus et al., 2015 for recent examination of this issue). 
In contrast, initial secondary market prices fail to impound fundamental information. Public investors' inability to access such scores could in fact account for the wildly inefficient pricing processes evident in the initial listing period. More generally, the stock return associations we identify suggest that the market requires some considerable time in gauging issuer fundamentals. This study's results suggest that public dissemination of fundamental information at IPO would materially reduce information asymmetries and lessen adverse selection risks. In essence, and in keeping with Merton's (1987) Investor Recognition Hypothesis, release of fundamental information speeds the process to a more stable secondary market.

In pursuing this study's objectives, Section 2 outlines the major research questions. Section 3 describes the central features of the data sample and the characteristics of the backdated CM scores available to us. Description of our empirical method, design and regression models then figures in Section 4. Results and conclusions follow in Sections 5 and 6.

\section{Research questions and hypotheses}

Our study broadly divides into two parts. We first assess A-listed IPO firms' post-listing stock returns. In a second stage, we examine fundamental performance, as captured by a listing entity's return-on-assets (ROA) and return-on-equity (ROE).

In relation to the first stage, a wide-ranging literature documents the factors that potentially underlie initial and longer-term post-listing returns ${ }^{7}$. The present study significantly extends this literature by assessing how a company's credit condition impacts on such returns. We also emphasize the need to interpret initial stock return performance in relation to longer-run horizons. Initial underpricing, or more specifically the return between final offer price and subsequent first secondary market $\operatorname{close}^{8}$, must be interpreted in relation to longer-run postlisting returns. For example, a raft of IPO studies documents positive initial returns but generally weak longer-run returns. ${ }^{9}$ Interpretation of such initial returns as evidence of IPO underpricing is thus problematic. Indeed, Purnanandam and Swaminathan (2004) point to overvaluation of final offer prices in many IPOs, relative to fair or intrinsic value benchmarks. They determine such benchmarks using relevant industry-related price multiples (including price/earnings). Their principal finding is that the run-up in secondary market price on first listing day often takes place

\footnotetext{
7. For the mainland Chinese market-place, see Chi and Padget (2005a), Gao (2010), Chan and Lo (2011), Gounopoulos et al. (2013), Jiang et al. (2014) and Song et al. (2014). In relation to the post-IPO performance of Alisted firms, see Chen et al. (2000), Sun and Tong (2003), Chan et al. (2004), Fan et al. (2007), Cai et al. (2008), Chi et al. (2010) and Chan and Lo (2011). For Hong Kong, see McGuinness (2016).

8. Underpricing is a recurrent theme across listing jurisdictions. For example, Boulton et al. (2010) reveal mean positive initial returns across a range of market settings and periods.

9. For review of such studies, see Thomadakis et al. (2012: p. 120-121).
} 
despite overvaluation of the IPO firm's issue price relative to fair value. Indeed, Purnanandam and Swaminathan (2004) reveal a strong inverse relation between longer-run post-listing returns and the ratio of final offer price to intrinsic value.

Gao (2010) formally operationalizes the Purnanandam and Swaminathan (2004) model by dichotomizing initial investor returns in Chinese A-share IPOs into "deliberate underpricing" and "aftermarket overpricing" components. Jiang et al. (2014) extend this conception to examination of VC-backed Chinese IPOs. ${ }^{10}$ Consistent with such approaches, we decompose the conventional initial return into a fundamental (FUNDret) and market-based return (MARKret). FUNDret is the ratio of intrinsic share value to final offer price, and MARKret is the ratio of first closing traded price to intrinsic share value.

In relation to short-run stock returns, we offer Hypothesis 1a.

Hypothesis 1a: CM scores exhibit inverse association with initial investor returns, as well as with the two underlying measures (FUNDret and MARKret).

For longer-run stock returns, we offer Hypothesis $1 \mathrm{~b}$.

Hypothesis 1b: Higher CM scores presage stronger post-IPO stock returns.

Rejection of H1a may arise if pricing inefficiencies and/or severe information asymmetries plague the market. One of the most obvious information gaps relates to an IPO firm's true earnings prospects. Many Chinese IPOs have limited pre-IPO earnings records, especially those launched on the Shenzhen SME and ChiNext boards. Subscribers therefore face an additional layer of uncertainty when evaluating such firms' prospects. Even for firms with a pre-IPO earnings record, the possible use of discretionary management accruals may confound attempts to form an accurate benchmark of pre-IPO profitability (see related evidence in Ahrony et al., 2000 for China; and Teoh et al., 1998 and DuCharme et al., 2001 for the US). ${ }^{11}$

Management of earnings or issues of market-timing, i.e., a firm pitching an IPO at an earnings peak, reinforces the adverse selection problem confronting subscribers. In such an environment, credit ratings (see, for example, Chou, 2013) and credit scores both potentially offer insights into future fundamental performance. As Chinese IPO investors are largely deprived credit rating information, it likely takes secondary market investors some considerable time to decipher a listing firm's earnings quality and trajectory. In such a setting, CM scores may

\footnotetext{
10. The literature also stresses the importance of VC-backing in relation to initial pricing. Specifically, pre-IPO investors help certify (Megginson and Weiss, 1995) and monitor (Barry et al. 1990) issuer quality.

11. By way of contrast, Ball and Shivakumar (2008) for US and UK new listings report that many firms report fairly conservative pre-IPO earnings numbers.
} 
offer weak association with initial stock returns; but a much stronger one with post-IPO earnings releases. Quarterly post-IPO earnings disclosures thus play a vital role in adjusting investors' perceptions of longer-term fundamentals. We therefore conjecture that CM scores help lessen the information gap between insiders and IPO investors on a firm's post-listing earnings trajectory. Accordingly, Hypothesis $\mathrm{H} 2$ asserts that,

Hypothesis 2: Higher CM scores presage stronger post-IPO earnings performance.

In assessing the two major hypotheses, the present study controls for a range of firm-and market-wide factors that potentially mediate post-IPO stock and fundamental earnings performance. Section 4 describes the form of such variables, as well as the structure of our empirical design.

\section{Sample characteristics}

The present study focuses exclusively on Chinese issuers listing in A-share market form on the Shanghai (SHSE) and Shenzhen (SZSE) stock exchanges. We consider such listings for the period June 2009 to October 2012. Two major regulatory interventions or moratoria surround this period. During the nine-month period running-up to June 2009, the China Securities Regulatory Commission and the two respective front-line exchange regulators imposed a wholesale ban on all IPO activities. From late October 2012, the authorities imposed a further proscription on A-share IPOs, suspending the primary market for around 14 months. Mainland Chinese IPO activity only resumed in early 2014. Our sample-frame is therefore defined by two important breaks in the primary market.

By focusing on a 2009 to 2012 sample-frame we ensure a more or less common regulatory platform for IPO pricing and share allocations. ${ }^{12}$ Control for regulatory change is crucial in understanding short-term returns. The marked contraction in mean initial returns on SHSE and SZSE IPOs over the 1990 to 2009 period strongly correlates with the sequence of pricing, quota and book-building reforms instituted over this 20-year period. Despite such reforms, initial return levels remain high relative to other Asia-Pacific markets that attract Chinese issuers. ${ }^{13}$

Our selected sample-frame allows for analysis of more than 866 A- share IPOs. Back-dated CM scores exist for the majority of the population of A- share firms listing through IPO during

\footnotetext{
12. See Song et al. (2014) for discussion of the key 2009 IPO reforms instituted in China.

13. Song et al. (2014), for 948 mainland IPOs pitched between 2006 and 2011, report mean unadjusted initial returns of more than 66 percent. In marked contrast, McGuinness (2012) finds mean unadjusted initial returns of less than 15 percent for 269 IPOs launched on Hong Kong Exchanges and Clearing Limited between 2005 and 2009.
} 
this period. Application of an S\&P Global Market Intelligence "imputation algorithm" allows for examination on a further 144 firms from within the 2009 to 2012 sample-frame. ${ }^{14}$

Table 1 summarizes the data for the 2009 to 2012 sample-frame. Around 36 percent of the 866 A- share IPO cases have back-dated CM scores computed in respect of incomplete financial data. S\&P Global Market Intelligence (for short, S\&P hereafter) qualify such scores with the proviso "interpret with caution", and the 64 percent of CM data points based on complete financial data as "clean" scores. As an important further qualification, S\&P advises that their computed CM scores exclusively reflect IPO firm financials. Such scores thus exclude any reference to a parent's financials or possible credit enhancement from government or staterelated owners. To help interpret the incremental explanatory power of CM scores, we control for a wide range of firm and market level effects that potentially shape post-IPO stock and fundamental returns. We construct such variables using data from GTA-CSMAR ${ }^{15}$.

\section{Variables and empirical methods employed}

In our examination of initial returns, we propose the following equation:

$$
\begin{aligned}
& \operatorname{Ret}_{i}= \\
& \beta_{0}+\beta_{1} \cdot \text { CM }_{i}+\beta_{2} \text {. Netproc_Equity }+\beta_{3} \text {. Sentiment } \text { S }_{i}+\beta_{4} \text {. Hot_Cold } i t+\beta_{5} \text {. } \\
& \text { Car_90 }+\beta_{6} \text {. Issuer_Size }+\beta_{7} \text {. D_002 }+\beta_{8} \text {. D_300 }+\beta_{9} \text {. Prestige }{ }_{i}+\beta_{10} \text {. } \\
& \text { Offer_Range }_{i}+\beta_{11} \text {. } \text { State }_{i}+\beta_{12} \text {. } \text { LegalPerson }_{i}+\beta_{13} \text {. } \text { Leverage }_{i}+\beta_{14} \text {. } \\
& \text { D_Growth_Earn }{ }_{\mathrm{i}}+\beta_{15} \beta_{28} \text {. Ind_Dummies } \mathrm{i}_{\mathrm{i}}+\mathrm{e}_{\mathrm{i}} \\
& \text { (Equation 1) }
\end{aligned}
$$

Likewise, for longer-run returns we propose the following equation form:

\section{BHAR or CAR $_{\mathrm{i}}=$}

$\beta_{0}+\beta_{1} \cdot \mathrm{CM}_{\mathrm{i}}+\beta_{2}$.ab_day1_ipo+ $\beta_{3}$. Netproc_Equity $+\beta_{4}$. Sentiment ${ }_{\mathrm{i}}+\beta_{5}$. Hot_Cold $_{\mathrm{i}}+\beta_{6}$. Car_90 $+\beta_{7}$. Issuer_Size $+\beta_{8}$. D_002 $+\beta_{9}$. D_300 $+\beta_{10}$. Prestige $_{i}+\beta_{11}$. Offer_Range ${ }_{i}+\beta_{12}$. State ${ }_{i}+\beta_{13}$. LegalPerson ${ }_{i}+\beta_{14}$. Leverage $_{i}+\beta_{15}$. D_Growth_Earn $i+\beta_{16}-\beta_{27}$. Ind_Dummies ${ }_{i}+e_{i}$

(Equation 2)

Equation 2 links buy-and-hold (BHAR) and cumulative abnormal (CAR) stock returns with a range of causal factors, including our primary variable of interest, the S\&P Credit Model $(\mathbf{C M})$ Score. Equation 1 first controls for the general level of market ebullience (variable Sentiment) at the time of IPO launch. Similar to Bradley and Jordan (2002), we consider the mean level of initial returns on IPOs launched within the 30 day period preceding a given entity's new listing. Variable Hot_Cold identifies the presence of 'hot' and 'cold' issue markets (Ibbotson, 1974; and Ritter, 1984). We capture such effects in terms of an IPO clustering measure; specifically, the

\footnotetext{
14. Special thanks are due Michelle P. Cheong and Clemens Thym of S\&P Global Market Intelligence for supplying back-dated CM score data on A-share IPO firms.

15. http://www.gtadata.com/products/plist.aspx.
} 
number of A-share IPOs launched over the 30 day period leading up to a given entity's own listing. Further control for general market effects features in terms of variable, Car_90, the cumulative return for the market index over the 90-day period prior to listing.

Firm size is also pivotal (Boulton, Smart and Zutter, 2010). We capture it in terms the market capitalization of an issuer's listed equity (Issuer_Size). The exchange venue of listing may also impact on stock returns. Variables D_002 and D_300 figure in Equation 1 as respective dummies for entities listed on the Shenzhen SME market-place and Shenzhen ChiNext boards. Control for the IPO firm's gearing figures through variable Leverage. Furthermore, 17 industry dummies (D_a to D_q) serve in capturing the IPO firms' business sector affiliations.

The quality of underwriters assigned is also central to explanations of IPO underpricing (see for example Beatty and Ritter, 1986; and Carter and Manaster, 1990). These accounts suggest an inverse association between the quality of the underwriting team and initial return levels, with higher quality levels signalling lower levels of ex-ante uncertainty (Beatty and Ritter, 1986). Empirical evidence exists in support of an inverse underwriter-IPO underpricing relation for Chinese A-share IPOs (see Guo and Brooks, 2008). In the present context, Prestige captures underwriter quality. We construct this variable by counting the number of IPOs the lead underwriter has handled prior to the IPO in question. We then divide this number by the total number of IPOs conducted on the Chinese mainland prior to the IPO in question.

We include two further measures, D_Growth_Earn and D_Range, to control for other dimensions of ex-ante uncertainty. The first measure captures uncertainty with regard to future earnings and the second the level of uncertainty surrounding an issuer's first secondary market price. For the latter, we conjecture that issues with a variable offer price are more likely to be priced closer to initial secondary market prices than fixed-price offers. IPOs with an offer price range afford underwriters greater latitude in aligning final offer prices with subscription demand.

In relation to fundamental accounting performance, we test the following equation:

$$
\begin{aligned}
& \mathrm{ROA}_{\mathrm{i}}\left(\text { or } \mathrm{ROE}_{\mathrm{i}}\right)=
\end{aligned}
$$

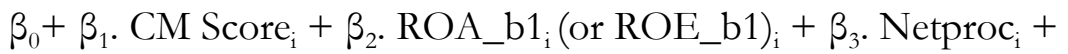

$$
\begin{aligned}
& \beta_{4} \text { Issuer_Size }_{i}+\beta_{5} \text {. D_002 }+\beta_{6} \text {. D_300 }+\beta_{7} \text {. Prestige } \text {. }_{i}+ \\
& \beta_{8} \text {. D_Range }{ }_{i}+\beta_{9} \text {. } \text { State }_{i}+\beta_{10} \text {. } \text { LegalP }_{i}+\beta_{11} \text {. } \text { leverage }_{i}+ \\
& \beta_{12} \text {. d_Growth_Earn }{ }_{i}+\beta_{13}-\beta_{26} \text {. Ind Dummies }{ }_{i}+e_{i} \text { (Equation 3) }
\end{aligned}
$$

All definitions of explanatory variables in Equation 3 are as earlier, though we naturally exclude Sentiment, Car_90 and Hot_Cold, which specifically relate to the degree of primary and secondary market ebullience at the time of an issuer's IPO. A priori, such variables should have little to do with an issuer's stream of post-IPO earnings. In their place we include the issuer's return-on-assets for the year-end immediately prior to IPO (ROA_b1). 
Finally, Appendices 1 and 2 report definitions (and summary statistics) for all variables.

\section{Results}

\subsection{Univariate Analysis}

Table 1 presents descriptive statistics for CM scores. Six levels exist within the study sample, ranging from the lowest assigned score, $\mathrm{b}-$, to the highest, $\mathrm{bb}+$. We consider each of the six levels in relation to comment type (that is, a CM score with proviso "interpret with caution" and one without, i.e., a "clean" score), industry of IPO firm, year of listing and exchange board chosen. For the latter, we note four possible board venues: The Shanghai Stock Exchange Main Board, Shenzhen Main Board, Shenzhen SME and Shenzhen ChiNext. Proscriptions on domestic cross-listings mean that an issuer is unable to have A-shares on two or more boards.

The vast majority of available CM scores are clustered in b+ and bb- categories. Very few cases exist in the highest $(\mathrm{bb}+)$ and lowest categories (b-). Accordingly, we merge the six categories into four groups. The CM Score groupings are as follows: Category 1 for firms with CM scores of either b- or b; Category 2 for b+ scores; Category 3 for bb- scores; and finally Category 4 for firms with either bb or bb+ scores.

Table 2 results complement those in Table 1. They reveal key statistics for CM scores in terms of an issuer's price-earnings ratio, subscription rate, issue cost, first day return and first day turnover level. The univariate statistics offer some evidence of a positive relation between $\mathrm{CM}$ score and PE ratio. For the full sample, PE ratios increase monotonically with CM score over the range b- to bb. This relationship is confirmed for the sub-sample of firms with "clean" comments, but not in respect of those with CM scores labelled with the "interpret with caution" proviso. Table 2 also suggests that better credit condition reduces a firm's cost of capital. CM scores are strictly decreasing in the proportion of gross proceeds absorbed in direct issue costs (Per Yuan Cost). This applies in respect of the whole sample, as well as for the "clean" and "qualified" CM score subsamples.

In terms of the initial market reaction to CM scores, Table 2 results suggest that $\mathrm{CM}$ scores bear a nonlinear relation with both IPO subscription rates and first-day turnover levels. Both associations reach a peak at $\mathrm{CM}$ score $\mathrm{b}+$, decreasing thereafter (i.e., over the range bb- to bb). We observe a similar nonlinear pattern when assessing the CM scores' association with first day market-adjusted returns. The suggestion is that initial market reaction is largely sentiment-driven. 
To shed further light on the initial market reaction, and in accordance with Purnanandam and Swaminathan (2004), Gao (2010) and Jiang et al. (2014), we decompose the conventional underpricing return measure into two constituent parts. The first component is fundamental underpricing (FUNDret). This dimension captures the difference between an IPO firm's intrinsic value and final offer price. The second or residual component captures the pricing gap (MARKret) between the IPO firm's intrinsic value and first closing secondary market price.

Table 3 reports descriptive statistics for both components, FUNDret and MARKret. Given the small number of stocks at the either end of the credit score and to allow for meaningful comparison, we cluster CM scores into four sub-groups. In respect of FUNDret, final offer prices appear closer to issuer intrinsic value in firms with higher CM scores. This suggests that underwriters and issuers have incorporated some of the information relevant to credit scores in final offer prices. However, the immediate post-IPO market reaction suggests non-uniform effects. This evidence confirms the nonlinear pattern revealed in Table 2 and thus suggests that the non-monotonic relation between $\mathrm{CM}$ score and conventional underpricing principally relates to initial trading effects. Table 3 results, at least in respect of CM scores across Categories 1-3, suggest that underwriters price firms with stronger CM scores closer to fundamentals (FUNDret), while initial market traders promote higher secondary market price run-ups (MARKret) in such firms. Companies with better financials (i.e.., higher CM scores) thus appear to excite the market more. Univariate results in Table 3 also suggest that IPO firms with stronger credit scores benefit from generally higher price-to-earnings ratios. Category 1 firms (i.e., those with the lowest $\mathrm{CM}$ scores of $\mathrm{b}$ and $\mathrm{b}-$ ) are responsible for most of the difference. Firms in Categories 2-4 have noticeably higher price-to-earnings ratios.

Univariate statistics in Table 3 also reveal that firms with stronger CM scores experience more favourable buy-and-hold returns over the first 12 months of listing (B\&Hret). More generally, the univariate results bear out global evidence of weak post-IPO returns relative to relevant market-adjusted benchmarks. However, Table 3 evidence reveals that firms with the strongest CM scores (i.e., those in Category 4), register performance contrary to this trend. Indeed Category 4 firms are the only group with positive mean market-adjusted buy-and-hold returns over one-year horizons. This provides supporting evidence to our Hypothesis 1b.

Overall, initial returns (Underpr) dropped markedly in the aftermath of China's 2009 IPO reforms. ${ }^{16}$ Such returns are appreciably lower than those recorded in 2006-8 (as indicated in Song,

\footnotetext{
16. Cao et al. (2016) report mean initial returns for 783 Shenzhen-listed IPOs, pitched between the IPO market open of July 2009 and close of November 2012, of just under 37 percent. Such levels are comparable to those reported in our study for IPOs in each of China's equity markets, Shanghai and Shenzhen.
} 
2014, p. 43). For the 1992 to 2006 period, Cheung et al. (2009: p. 698) report initial returns in China A-share IPOs of more than 133 percent.

\subsection{Regression analysis}

The univariate statistics in Tables 2 and 3 broadly suggest that CM scores offer value in understanding short- and long-run stock returns in Chinese A- share IPOs. Multivariate regression results in Tables $4 \mathrm{a} \& 4 \mathrm{~b}$ offer more refined insight by allowing assessment of $\mathrm{CM}$ scores' explanatory power over and above well-known control factors. All such regressions also include robust error corrections and control for unobservable heterogeneity through industry and fixed (years) effects. Variance inflation factors also suggest the absence of major multicollinearity effects.

The multivariate analysis in Table 4a indicates that the explanatory power of CM scores generally weakens after inclusion of control effects like firm size (Issuer_Size), underwriter reputation (Prestige) and earnings growth (D_Growth_Earn). Results reject our Hypothesis 1a that CM scores exhibit an inverse association with initial return levels, as well as with each of the two underlying components of initial returns.

As shown in Table 4b, CM scores display positive association with longer-term cumulative abnormal (CAR) and buy-and-hold (BHAR) returns. Thus, after account of firm- and marketrelated variables, CM scores offer some incremental power in explaining medium to longer-term issuer value. However, significance levels wane somewhat at three-year horizons relative to those evident at earlier windows; specifically, at one- and two- year horizons. In reconciling findings across Tables $4 \mathrm{a}$ and $\mathrm{b}$, we surmise the following. As CM scores are not in the public domain and therefore unobservable, the fundamental information they contain may go unrecognized in the initial listing period but becomes confirmed by issuers' subsequent accounting disclosures. This picture is consistent with the Merton (1987) Investor Recognition Hypothesis in that it takes time for investor to know the IPO companies.

Our evidence therefore supports Hypothesis $1 \mathrm{~b}$ that higher CM scores presage stronger post-IPO stock returns. Longer-term corroboration of fundamental value, as revealed through post-IPO accounting disclosures, analyst reports and other announcements, gradually feeds into market prices. Findings are also consistent with some of this information being encapsulated in CM scores. Ceteris paribus, revelation of such scores should promote better price-discovery, thus 
lessening information asymmetries and potential adverse selection issues. ${ }^{17}$ This interpretation suggests that CM scores strongly anticipate post-IPO earnings. Tables 5 and 6 address this issue.

Table 5 results reveal CM score associations with post-IPO return-on-assets (ROA). Strong effects are apparent from the end of the second quarter (i.e., after around 6 months of listing). Such effects remain resilient thereafter, all the way up to the end of the twelfth quarter (i.e., 36 months after initial listing). A similar pattern emerges when examining return-on-equity (ROE) results in Table 6. However, the ROE effects of CM scores only become apparent from the end of the third quarter (rather than second quarter in respect of ROA results). In addition, CM scores display stronger longer-run association with the ROE measure.

\subsection{Robustness Checks}

In deepening findings, we also consider different groupings for the pivotal categorical credit score variable. Variable CM1 captures credit ratings over three levels, and has the following construction: Categorical value 3 for credit model scores of bb+ or bb; 2 for score of bb-; and 1 for scores of $\mathrm{b}+$, b or $\mathrm{b}-.^{18}$ As with our earlier analysis, we consider this refined formulation in relation to both after-market pricing and accounting return (ROA \& ROE) effects. Tables 7-9 document relevant results.

Findings for variable CM1 appear broadly similar to earlier results in respect of CM (Tables 4-5). In Table 7 we consider post-IPO returns for trading horizons of one-, two- and three-years (i.e., trading horizons of 250, 500 and 750 business days). For reasons of robustness, we report stock returns in both buy-and-hold (BHAR) and cumulative abnormal return (CAR) forms. For one-year horizons, CM1 bears significant association with both return forms at the 10 percent level. Over two-years, the p-level for both performance forms increases to the extent that CM1 exhibits significance with post-IPO stock returns at the 5 percent level. However, the positive association weakens over three-year horizons in respect of both BHAR and CAR measures.

Tables 8-9 document CM1 effects in relation to accounting performance variables, namely return-on-assets (ROA) and return-on-equity (ROE). Consistent with earlier findings, in relation to variable $\mathrm{CM}$, the positive association between credit model score and performance is considerably more pronounced when assessing accounting returns. Additionally, the ROE measure is more responsive than ROA (in terms of significance levels) to credit model score

17. As instructive background, Pan et al. (2015) reveal that improvement in Taiwan-listed firms' disclosure-ratings serves in squeezing adverse selection costs and encouraging subsequent equity issuance. Kisgen (2006) demonstrates that firms are more likely to issue equity than debt if ratings are close to credit rating thresholds. The implication is that equity issuance helps ward-off downgrade for firms narrowly above a threshold, but supports upgrade for those in the upper range of a rating interval.

18. We thank comment from Michelle P. Cheong in directing us to this alternative credit grouping measure. 
variation. In general terms, significant effects are signalled much more strongly in regressions of financial returns (notably, at levels of 5 and 1 percent in particular regressions) than in the stock return regressions in Tables $4 \mathrm{~b} \& 7-8$ (where significant effects are evident in a few regressions at the 5 percent level but more often than not at 10 percent levels). CM variable effects also appear to be more relevant to a continuum of financial returns, stretching from post-listing end-ofquarter periods 2 to 12 in respect of both ROA and ROE measures (see Tables 5 -6).

Overall, the results in this study describe an environment in which CM scores offer prescriptive value in potentially lessening information asymmetries. In relation to Chinese Ashare IPOs, we show that this value is quickly reflected in post-IPO earnings but only gradually impounded into secondary market prices. Such results are congruent with credit model scores' greater association with fundamental performance. We surmise that fundamentals may be obscured by major inefficiencies in mainland Chinese PRC stock pricing.

\section{Conclusions and areas of further investigation}

Our analysis of S\&P Global Market Intelligence's CreditModel (CM) scores is instructive in two important ways. First, we offer insight into such scores' incremental value and thus their valuerelevance. Second, and more importantly, we demonstrate that, in an environment where such scores lie outside the public domain, pricing inefficiencies and marked informational asymmetries characterize initial stock return patterns. CM scores thus contain potential prescriptive value.

A major implication of this study's findings is that dissemination of CM scores offers a mechanism for reducing information asymmetries and related adverse selection risks in the context of the Chinese A-share IPO market. CM scores thus offer an additional source of information for issuers, intermediaries, analysts and subscribers to Chinese A-share IPOs. Up to the present time, such parties have faced huge levels of underpricing and after-market volatility in this setting.

The present study's investigation of back-dated CM scores also conveniently avoids the signalling issues that plague assessment of the information value of publicly-disclosed credit ratings. We also sidestep the confounding self-selection issue. Our investigation thus offers new insight into the information benefits of credit evaluation, without the biases that contaminate conventional analysis of publicly-disclosed credit-ratings.

Our results also contribute to the debate on the parties who potentially benefit from credit model score information. We show that a CM score's information content is partially 
incorporated into final offer pricing levels and also subsumed by other fundamental variables (such as issuer size and underwriter quality). Revelation of credit model information to professionals (underwriters) and insiders (company managers and IPO firm controllers) may therefore yield only a limited amount of incremental value. Investors trading in the initial secondary market potentially gain the most from the release of CM scores.

Importantly, we find that an IPO firm's CM score embeds information helpful in gauging future earnings streams and that longer-term buy-and-hold returns capture such fundamentals. However, initial secondary market prices do not readily incorporate this fundamental information. Sentiment effects, as perhaps compounded by the overwhelming presence of retail investors in the Chinese A-share market, drive a wedge between initial market and underlying intrinsic values. The pattern of stock market return associations we uncover is also consistent with the Merton (1987) Investor Recognition Hypothesis. In respect of China, our evidence suggests that it takes some considerable time for post-listing prices to incorporate relevant fundamental information. Dissemination of credit model scores would likely hasten investors' assessment of intrinsic value. It might also temper volatility and induce more stable turnover in a stock's initial trading period.

In terms of further areas of investigation, credit scores also likely inform in relation to firm survival. Various empirical accounts stress the importance of financial ratios in discriminating between a firm's longer-term survival (solvency) and failure (non-solvency). This literature has considerable pedigree, with Altman (1968) and Ohlson (1980) serving as important milestones or highlights. For Pacific-Rim markets, Kuo et al. (2003), in respect of Taiwan, and Chen et al. (2006), for the mainland PRC, identify salient financial ratios relevant to longer-run firm survival. Analysis of composite-style financial measures, most notably credit model scores, would add important nuance to accounts of the antecedent characteristics of firm survival/bankruptcy.

The recent public dissemination of S\&P Global Market Intelligence's Credit Model (CM) scores potentially allows for examination of disclosure effects on initial secondary market pricing. Nonetheless, focus on this issue is impeded by two major concerns. The first is the moratorium imposed on Chinese A-share IPOs between November 2012 and December 2013. The second is the regulatory overhaul of IPO disclosure practice and the implementation of new standards in the aftermath of the extended 14-month moratorium (November 2012 - December 2013) on Ashare IPOs in early 2014. This second consideration suggests a slightly different information environment post-2013. Nonetheless, we conjecture that broad dissemination of credit quality evaluations would further enrich the post-2013 Chinese A-share IPO information environment. 


\section{References}

Ahrony, J., Jevons-Lee, C.W., Wong, T.J., 2000 Financial packaging of IPO firms in China, Journal of Accounting Research, 38(1): 103-126.

Altman, E.I., 1968. Financial ratios, discriminant analysis and the prediction of corporate bankruptcy. The Journal of Finance, 23(4): 589-609.

An, A. and Chan, K.C., 2008. Credit ratings and IPO pricing. Journal of Corporate Finance, 14: 584595.

Ball, R., Shivakumar, L., 2008. Earnings quality at initial public offerings, Journal of Accounting and Economics, 45: 324-349.

Bannier, C.E., Behr, P., Guttler, A., 2010. Rating opaque borrowers: Why are unsolicited ratings lower? Review of Finance, 14: 263-294.

Barry, C.B, Muscarella, C.J., Peavy, J.W., Vetsuypens, M.R., 1990. The role of venture capital in the creation of public companies, Journal of Financial Economics, 1990, 27: 447-471.

Beatty, R.P., Ritter, J.R., 1986. Investment banking, reputation, and the underpricing of initial public offerings, Journal of Financial Economics, 15: 213-32.

Bradley, D.J., Jordan, B.D., 2002. Partial adjustment to public information and IPO underpricing, Journal of Financial and Quantitative Analysis, 37: 595-616.

Boulton, T.J., Smart, S.B., Zutter, C.J., 2010. IPO underpricing and international corporate governance, Journal of International Business Studies, 41: 206-22.

Byoun, S., Fulkerson, J.A., Han, S.H., Shin, Y.S., 2014. Are unsolicited ratings biased? Evidence from long-run stock performance, Journal of Banking and Finance, 42: 326-338.

Cai, X., Liu, G., Mase, B., 2008. The long-run performance of initial public offerings and its determinants: the case of China. Review of Quantitative Finance and Accounting, 30 (4): 419-432.

Cao, J., Leng, T., Liu, B., Megginson, W., 2016. Institutional bidding in IPO allocation: Evidence from China. AFA/ASSA Meeting, 3-5 January 2016, San Francisco (available at: https://www.aeaweb.org/conference/2016/retrieve.php?pdfid=1537).

Carter, R., Manaster, S., 1990. Initial public offerings and underwriter reputation, The Journal of Finance, 45: 1045-67.

Chan, K., Wang, J.B., Wei, K.C., 2004. Underpricing and long-term performance of IPOs in China. Journal of Corporate Finance, 10 (3): 409-30.

Chan, K. C., Lo, Y.L., 2011. Credit ratings and long term IPO performance. Journal of Economics and Finance, 35:473-483.

Chen, G., Firth, M., Kim, J.B., 2000. The Post-Issue Market Performance of Initial Public Offerings in China's New Stock Markets. Review of Quantitative Finance and Accounting, 14(4): 319-39.

Chen, J., Marshall, B.R., Zhang, J., Ganesh, S., 2006. Financial distress predictions in China. Review of Pacific Basin Financial Markets and Policies, 9(2): 317-336.

Cheng, M., Subramanyam, K.R., 2008. Analyst following and credit ratings. Contemporary Accounting Research, 25(4): 1007-1043.

Cheung, Y. L., Ouyang, Z., Tan, W., 2009. How regulatory changes affect IPO underpricing in China. China Economic Review, 20: 692-702.

Chi J., Padgett, C., 2005a. Short-run underpricing and its characteristics in Chinese initial public offering markets. Research in International Business and Finance, 19(1): 71-93.

Chi, J., Padgett, C., 2005bThe performance and long-run characteristics of the Chinese IPO markets. Pacific Economic Review, 10 (4): 451-69.

Chi, J., Wang, C., Young, M., 2010. Long-run outperformance of Chinese initial public offerings. The Chinese Economy, 43 (5): 62-88.

Chou, T.-K., 2013. Information content of credit ratings in pricing of future earnings. Review of Quantitative finance and Accounting, 40: 217-250.

Deb, S.S., Marisetty, V.B., 2010. Information content of IPO grading. Journal of Banking and Finance, 2010, 34: 2294-2305.

Doumpos, M., Niklis, D., Zopoundis, C., Andrioopoulos, K., 2015. Combining accounting data and a structural model for predicting credit ratings: Empirical evidence from European listed firms. Journal of Banking \& Finance, 50: 599-607. 
DuCharme, L.L., Malatesta, P.H., Sefcik, S.E., 2001. Earnings management: IPO valuation and subsequent performance, Journal of Accounting, Auditing and Finance, October: 369-396

Fan, J.P., Wong, T.J., Zhang, T.Y. 2007. Politically connected CEOs, corporate governance, and postIPO performance of China's newly partially privatized firms. Journal of Financial Economics, 84 (2): 330-57.

Gao, Y., 2010. What Comprises IPO Initial Returns: Evidence from the Chinese Market. PacificBasin Finance Journal, 18: 77-89.

Gounopoulos, D., Guney, Y. and Xu, T., 2013. Do credit ratings affect underpricing and volatility? Evidence from Chinese IPOs, Unpublished manuscript (available at: http://www.fma.org/Luxembourg/Papers/CreditRatingChineseIPOs.pdf).

Habib, M.A., Ljungqvist, A.P., 2001. Underpricing and entrepreneurial wealth losses in IPOs: theory and evidence, The Review of Financial Studies, 14: 433-58.

Ibbotson, R.G., and Jaffe, J.F., 1975. "Hot issue" markets, The Journal of Finance, 30(4): 1027-1042. Jacob, J., Agarwalla, S.K., 2012. Mandatory IPO grading: Does it help pricing efficiency? Indian Institute of Management, Ahmedabad, Working Paper 2012-12-07, December 2012.

Jiang, P., Cai, C., Keasey, K., Wright, M., Zhang, Q., 2014. The role of venture capitalists in small and medium enterprises IPOs: Evidence from China, International Small Business Journal, 32(6): 619-643.

Kao, J.L., Wu, D.H., Yang, Z.F., 2009. Regulations, earnings management, and post-IPO performance: the Chinese evidence, Journal of Banking and Finance, 33 (1): 63-76.

Kisgen, D.J., 2006. Credit ratings and capital structure. The Journal of Finance, 61(3): 1035-1072.

Kuo, H.C., Wang, L.-H., Sheu, H.-J., Li, F.K., 2003. Credit evaluation for small and medium-sized enterprises by the examination of firm specific financial ratios and non-financial variables: Evidence from Taiwan. Review of Pacific-Basin Financial Markets and Policies, 6(1): 5-20.

Leland, H., Pyle, D., 1977. Information asymmetries, financial Structure and financial intermediation. The Journal of Finance, 32: 371-87.

Liu, Y., Malatesta, P., 2005. Credit ratings and the pricing of seasoned equity offerings, unpublished manuscript, 2005 (available at:

http://www.bm.ust.hk/fina/FinanceSymposium/2005Symposium/Papers/PaulMalatesta.pdf).

Mansi, S.A., Maxwell, W.F. and Miller, D.P., 2011. Analyst forecast characteristics and the cost of debt, Review of Accounting Studies, 16: 116-142.

McGuinness, P.B., 2012. The role of 'cornerstone' investors and the Chinese state in the relative underpricing of state- and privately-controlled IPO firms', Applied Financial Economics, 22(18):1529-1551.

McGuinness, P.B., 2016. Post-IPO performance and its association with subscription cascades and issuers' strategic-political importance, Review of Quantitative Finance and Accounting, 46(2): 291-333.

Megginson, W.L., Weiss, K.A., 1991. Venture capitalist certification in initial public offerings, The Journal of Finance, 66(3): 879-903.

Merton R., 1987. A simple model of capital market equilibrium with incomplete information, The Journal of Finance, 62(3): 483-510.

Ohlson, J.A., 1980. Financial ratios and the probabilistic prediction of bankruptcy. Journal of Accounting Research, 18(1): 109-131.

Pan, L.-H., Lin, C.-T., Lee, S.-C., Ho, K.-C., 2015. Information ratings and capital structure, Journal of Corporate Finance, 31: 17-32.

Poon, W, P.-H., Chan, K.C., 2008. An empirical examination of the informational content of credit ratings in China. Journal of Business Research, 61: 790-797.

Poon, W, P.-H., Chan, K. C., Firth, M.A., 2013. Does having a credit rating leave less money on the table when raising capital? A study of credit ratings and seasoned equity offerings in China, Pacific-Basin Finance Journal, 22: 88-106.

Purnanandam, A.K., Swaminathan, B., 2004. Are IPOs really underpriced? The Review of Financial Studies, 17(3): 811-848.

Ritter, J., 1984, 'The "Hot Issue" Market of 1980', Journal of Business, 57: 215-240.

Song, S., Tan, J., Yi, Y., 2014. IPO returns in China: Underpricing or overvaluation? China Journal of Accounting Research, 7: 31-49. 
Sun, Q., Tong, H.S., 2003. China Share Issue Privatization: The Extent of Its Success. Joumal of Financial Economics, 70(2): 183-222.

Teoh, S.H., Welch, I., Wong, T.J., 1998. Earnings management and the long-run market performance of initial public offerings, The Journal of Finance, 53: 1935-1974.

Tian, L., 2011. Regulatory underpricing: determinants of Chinese extreme IPO returns. Journal of Empirical Finance, 18 (1): 78-90.

Thomadakis, S., Nounis, C., Gounopoulos, D., 2012. 'Long term performance of Greek IPOs', European Financial Management, 18(1): 117-141. 
Table 1 Distribution of CM Score by rating comments, industry, year and listing board

This table reports the distribution of CM score by rating comments (Panel A), industry (Panel B), year (Panel C) and listing board (Panel B). CM score is reported the scores ranging from b- to bb+. A 'N' CM score indicates company is not the S\&P Global Market Intelligence file and A 'M' score indicates company is in the S\&P Global Market Intelligence file but no rating is given.

\begin{tabular}{|c|c|c|c|}
\hline \multicolumn{4}{|c|}{ Panel A Comments } \\
\hline CM_score & Interpret with caution & Clean & All \\
\hline $\mathbf{N}$ & 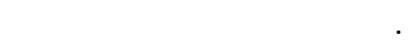 & 37 & 37 \\
\hline $\mathbf{M}$ & 4 & 7 & 11 \\
\hline b- & 4 & 4 & 8 \\
\hline b & 34 & 55 & 89 \\
\hline$b+$ & 105 & 186 & 291 \\
\hline bb- & 162 & 273 & 435 \\
\hline bb & 18 & 23 & 41 \\
\hline bb+ & . & 2 & 2 \\
\hline All & 327 & 587 & 914 \\
\hline
\end{tabular}

\begin{tabular}{|c|c|c|c|c|c|c|c|}
\hline \multirow[b]{2}{*}{ CM Score } & \multicolumn{7}{|c|}{ Panel B Industry } \\
\hline & Real Estate & Industrial & Public Service & Finance & Commercial & Mix & All \\
\hline $\mathbf{N}$ & 2 & 22 & 10 & 2 & 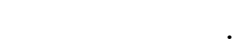 & 1 & 37 \\
\hline $\mathbf{M}$ & 2 & . & . & 9 & . & . & 11 \\
\hline b- & . & 6 & 2 & . & . & . & 8 \\
\hline b & 3 & 79 & 3 & . & 3 & 1 & 89 \\
\hline $\mathrm{b}+$ & 3 & 245 & 24 & . & 10 & 9 & 291 \\
\hline bb- & 5 & 297 & 116 & . & 8 & 9 & 435 \\
\hline bb & 2 & 29 & 3 & . & 2 & 5 & 41 \\
\hline$b b+$ & 1 & & 1 & . & . & . & 2 \\
\hline All & 18 & 678 & 159 & 11 & 23 & 25 & 914 \\
\hline
\end{tabular}




\begin{tabular}{|c|c|c|c|c|c|c|c|}
\hline \multirow[b]{2}{*}{ CM Score } & \multicolumn{6}{|c|}{ Panel C Year } & \multirow[b]{2}{*}{ All } \\
\hline & 2009 & 2010 & 2011 & 2012 & 2013 & 2014 & \\
\hline $\mathbf{N}$ & 6 & 12 & 6 & 8 & 2 & 3 & 37 \\
\hline $\mathbf{M}$ & 4 & 4 & 2 & 1 & . & t & 11 \\
\hline b- & . & 2 & 3 & 1 & . & 2 & 8 \\
\hline b & 6 & 37 & 30 & 14 & . & 2 & 89 \\
\hline$b+$ & 28 & 120 & 94 & 41 & . & 8 & 291 \\
\hline bb- & 49 & 157 & 134 & 83 & . & 12 & 435 \\
\hline bb & 6 & 15 & 13 & 7 & . & . & 41 \\
\hline bb+ & . & 2 & & & & & 2 \\
\hline All & 99 & 349 & 282 & 155 & 2 & 27 & 914 \\
\hline
\end{tabular}

\begin{tabular}{|c|c|c|c|c|c|c|c|}
\hline \multirow[b]{2}{*}{ CM Score } & \multicolumn{7}{|c|}{ Panel D Listing Board } \\
\hline & SZ A 000 & SZ SME 002 & ChiNext 300 & SH A 600 & SH A 601 & SH A 603 & All \\
\hline $\mathbf{N}$ & 1 & 10 & 11 & 1 & 13 & 1 & 37 \\
\hline M & . & 4 & . & 1 & 6 & . & 11 \\
\hline b- & . & 5 & 1 & . & 1 & 1 & 8 \\
\hline b & . & 56 & 20 & . & 9 & 4 & 89 \\
\hline $\mathrm{b}+$ & . & 170 & 93 & 1 & 22 & 5 & 291 \\
\hline bb- & . & 167 & 238 & . & 25 & 5 & 435 \\
\hline bb & . & 24 & 8 & . & 8 & 1 & 41 \\
\hline bb+ & . & & . & . & 2 & . & 2 \\
\hline All & 1 & 436 & 371 & 3 & 86 & 17 & 914 \\
\hline
\end{tabular}


Table 2 Summary of Key IPO variables

Panel A reports summary statistics of key IPO variables for the full sample. Panel B reports ratings by comment type. Variable definitions are as follows: PE after IPO is the price-to-earnings ratio after IPO. Per Yuan Costs is the total issue costs divided by total capital proceeds. Oversubscription rate is the total number of shares of valid subscriptions to total on offer. First day adjusted return is the first day market return minus market return. First day turnover is the number of shares traded on first day of listing divided by total number of tradable A- shares.

Panel A. Full sample

\begin{tabular}{|c|c|c|c|c|c|c|}
\hline & PE after IPO & Per yuan costs & $\begin{array}{r}\text { Over subscription } \\
\text { rate }\end{array}$ & $\begin{array}{r}\text { 1st day turn } \\
\text { over }\end{array}$ & $\begin{array}{r}\text { 1st day market } \\
\text { adjust return }\end{array}$ & Number of companies \\
\hline $\mathbf{N}$ & 39.99 & 0.06 & 127.42 & 0.66 & 0.58 & 37 \\
\hline $\mathbf{M}$ & 34.23 & 0.03 & 141.94 & 0.75 & 0.38 & 11 \\
\hline b- & 43.63 & 0.08 & 73.15 & 0.56 & 0.33 & 8 \\
\hline b & 44.57 & 0.07 & 138.44 & 0.68 & 0.33 & 89 \\
\hline$b+$ & 48.03 & 0.07 & 140.03 & 0.7 & 0.36 & 291 \\
\hline bb- & 50.92 & 0.07 & 126.41 & 0.68 & 0.36 & 435 \\
\hline bb & 52.26 & 0.06 & 94.85 & 0.66 & 0.22 & 41 \\
\hline bb+ & 37.28 & 0.02 & 44.08 & 0.46 & 0.02 & 2 \\
\hline All & 48.75 & 0.07 & 130.09 & 0.69 & 0.36 & 914 \\
\hline
\end{tabular}

Panel B. By comment types

\begin{tabular}{|c|c|c|c|c|c|c|}
\hline & PE after IPO & $\begin{array}{r}\text { Per yuan } \\
\text { costs }\end{array}$ & $\begin{array}{r}\text { Over subscription } \\
\text { rate }\end{array}$ & $\begin{array}{r}\text { 1st day turn } \\
\text { over }\end{array}$ & $\begin{array}{l}\text { 1st day market } \\
\text { adjust return }\end{array}$ & $\begin{array}{l}\text { Number of } \\
\text { companies }\end{array}$ \\
\hline \multicolumn{7}{|c|}{ Interpreted with caution } \\
\hline b- & 53.5 & 0.09 & 48.73 & 0.51 & 0.1 & 4 \\
\hline b & 46.26 & 0.07 & 104.78 & 0.68 & 0.28 & 34 \\
\hline$b+$ & 48.48 & 0.07 & 143.87 & 0.72 & 0.4 & 105 \\
\hline bb- & 47.46 & 0.08 & 133.45 & 0.71 & 0.44 & 162 \\
\hline bb & 48.06 & 0.06 & 103.41 & 0.68 & 0.24 & 18 \\
\hline All & 47.77 & 0.07 & 131.1 & 0.71 & 0.39 & 323 \\
\hline \multicolumn{7}{|c|}{ Clean } \\
\hline b- & 33.75 & 0.07 & 97.57 & 0.61 & 0.57 & 4 \\
\hline b & 43.53 & 0.07 & 159.25 & 0.68 & 0.36 & 55 \\
\hline$b+$ & 47.78 & 0.07 & 137.86 & 0.69 & 0.34 & 186 \\
\hline bb- & 52.97 & 0.07 & 122.23 & 0.67 & 0.32 & 273 \\
\hline bb & 55.56 & 0.05 & 88.15 & 0.64 & 0.2 & 23 \\
\hline bb+ & 37.28 & 0.02 & 44.08 & 0.46 & 0.02 & 2 \\
\hline All & 50.15 & 0.07 & 129.42 & 0.67 & 0.32 & 543 \\
\hline
\end{tabular}




\section{Table 3 IPO characteristics by credit score groups}

This table reports the IPO characteristics by credit score groups.

PE_postIPO is the price-to-earnings ratio after IPO.

Initial underpricing: FUNDret $=($ Intrinsic value $/ \mathrm{IPO}$ price $)-1$.

Intrinsic value is calculated as the value of the company imputed by the industry PE ratio: Intrinsic value $=$ Earnings before IPO*median industry PE ratio.

Market Reaction: MARKret $=($ First day close price/intrinsic value-1) - market return on the same day.

The index for the market return is sourced from CSMAR, which is a value weighted market return index for all stocks listed in the mainland Chinese market.

UnderPr $=($ First day closing price $/$ final offer price $)-($ market return on the first day of listing $)$.

Bhar_250 is the abnormal buy and hold return from the second day after IPO until one year later.

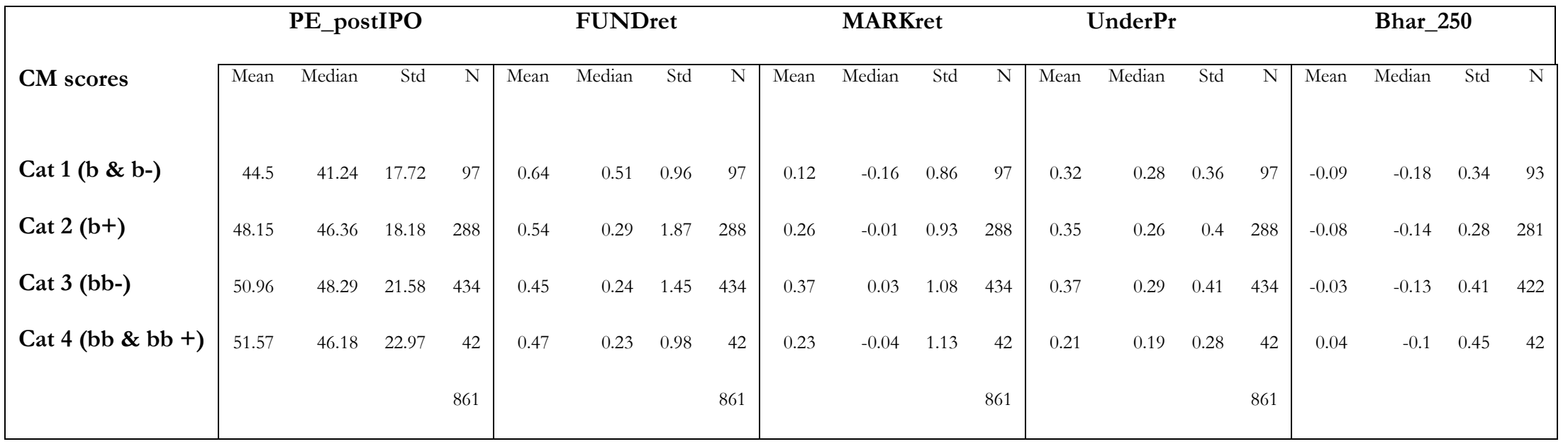




\section{$\underline{\text { Table 4a } \quad \underline{L S} \text { regressions of short-run returns featuring variable } \mathrm{CM}}$}

$\operatorname{Ret}_{i}=\beta_{0}+\beta_{1} \cdot C_{i}+\beta_{2}$. Netproc_Equity $+\beta_{3}$. Sentiment ${ }_{i}+\beta_{4}$. Hot_Cold ${ }_{i}+\beta_{5}$. Car_90 Hot $_{i}+\beta_{6}$. Issuer_Size $i$ $\beta_{7}$. D_002 $+\beta_{8}$. D_300 $+\beta_{\text {9 }}$. Prestige ${ }_{i}+\beta_{10}$. Offer_Range $i+\beta_{11}$. State ${ }_{i}+\beta_{12}$. LegalPerson $_{i}+$ $\beta_{13}$. Leverage $+\beta_{14}$. D_Growth_Earn ${ }_{i}+\beta_{15}-\beta_{28}$. Ind_Dummies ${ }_{i}+e_{i}$

(Equation 1)

\begin{tabular}{|c|c|c|c|c|c|c|c|c|}
\hline & \multicolumn{4}{|c|}{ Initial Underpricing (FUNDret) } & \multicolumn{4}{|c|}{ Market Reaction (MARKret) } \\
\hline & Coeff & P-Value & Coeff. & P-Value & Coe & P- & Coeff. & P-Value \\
\hline Intercept & 0.689 & 0.000 & 1.765 & $0.084 *$ & 0.0 & 0.43 & 3.807 & $0.000 * * *$ \\
\hline $\mathrm{CM}$ & -0.075 & 0.182 & 0.075 & 0.231 & 0.0 & 0.05 & -0.033 & 0.424 \\
\hline Netproc_Equity & & & -0.182 & 0.000 & & & 0.219 & $0.000 * * *$ \\
\hline Sentiment & & & -0.249 & 0.389 & & & 0.970 & $0.000 * * *$ \\
\hline Hot_Cold & & & 0.007 & 0.179 & & & -0.022 & $0.000 * * *$ \\
\hline Issuer_Size & & & -0.117 & 0.203 & & & -0.208 & $0.001 * * *$ \\
\hline Car_90 & & & -0.175 & 0.874 & & & 1.705 & $0.000 * * *$ \\
\hline D_002 & & & -0.237 & $0.079 *$ & & & -0.022 & 0.816 \\
\hline D_300 & & & -0.471 & $0.025 *$ & & & -0.067 & 0.550 \\
\hline Prestige & & & 4.350 & $0.061 *$ & & & -6.923 & $0.000 * * *$ \\
\hline Offer_Range & & & 0.019 & 0.777 & & & 0.023 & 0.723 \\
\hline State & & & -0.403 & $0.046 *$ & & & 0.565 & $0.007 * * *$ \\
\hline LegalPerson & & & -0.175 & 0.198 & & & 0.131 & 0.295 \\
\hline Leverage & & & 0.330 & 0.232 & & & -0.355 & $0.001 * * *$ \\
\hline D_growth_ea & & & 0.296 & 0.005 & & & -0.429 & $0.000 * * *$ \\
\hline Ind Dummies & \multicolumn{2}{|c|}{ No } & \multicolumn{2}{|c|}{ Yes } & \multicolumn{2}{|c|}{ No } & \multicolumn{2}{|c|}{ Yes } \\
\hline R-squared & \multicolumn{2}{|c|}{0.0002} & \multicolumn{2}{|c|}{0.0302} & \multicolumn{2}{|c|}{0.003} & \multicolumn{2}{|c|}{0.2771} \\
\hline $\mathrm{N}$ & \multicolumn{2}{|c|}{861} & \multicolumn{2}{|c|}{861} & \multicolumn{2}{|c|}{861} & \multicolumn{2}{|c|}{861} \\
\hline
\end{tabular}

Notes: $\left.\quad{ }^{* * *}\right),\left({ }^{* *}\right),\left({ }^{*}\right) \quad$ Indicates two-tailed significance at the one, five and ten percent levels, respectively.

Dependent variables:

Explanatory variables:
FUNDret $=$ Intrinsic value $/$ final offer price $)-1$; MARKret $\{=$ [(closing price/intrinsic value)-1]-(market return on first day) $]$.

CM (4 if CM_Score='bb+' or ='bb'; 3 if CM_Score='bb-'; 2 if CM Score='b+'; \& 1 if CM_Score='b' or 'b-'); Netproc_Equity (Ratio of proceeds from new IPO shares to the RMB book value of assets just prior to IPO); Sentiment (Average initial return on all A-share IPOs within 30-day period prior to entity's own IPO); hot_cold (Number of IPO within the 30-day period preceding a given entity's IPO); Issuer_Size (Logarithm of issuer's market capitalization ( $=$ No. of shares outstanding*final offering price); Car_90 (Cumulative abnormal return for the 90-day period leading-up to IPO (based on daily value-weighted market returns with cash dividends reinvested from all listed shares); D_002 (= 1 if the issuer lists on the Shenzhen SME market; otherwise 0); D_300 (= 1 if the issuer lists on the Shenzhen growth enterprise market; otherwise 0$)$; Prestige (Number of IPO the leading underwriter for the current IPO has conducted since market open divided by the total number of IPOs in the market from inception); Offer_Range; (Ratio of maximum OP/minimum OP); State (Percentage of state owned shares); LegalPerson (Percentage of legal person shares); Leverage (Long term debt divided by equity); D_Growth_Ear (= 1 if listing firm has positive growth in earnings over 3 years prior to IPO, otherwise 0); and D_a to D_q (Industry dummies). See Appendix 1 for detailed variable definitions (Appendix 2 for descriptive statistics). 


\section{$\underline{\text { LS regressions of long-run returns featuring variable } \mathrm{CM}}$}

$\operatorname{Ret}_{i}=\beta_{0}+\beta_{1} \cdot C_{i}+\beta_{2} \cdot$ ab_day1_ipo $+\beta_{3}$. Netproc_Equity $+\beta_{4}$. Sentimenti $+\beta_{5}$. Hot_Cold Hot $_{i}+\beta_{6}$. Car_90 $0_{i}+\beta_{7}$. Issuer_Size ${ }_{i}+$ $\beta_{8}$. D_002 $+\beta_{9}$. D_300 $+\beta_{10}$. Prestige $i+\beta_{11}$. Offer_Range $+\beta_{12}$. State $i+\beta_{13}$. LegalPerson L $_{i}+\beta_{14}$. Leverage $_{i}+$

$\beta_{15}$. D_Growth_Earn ${ }_{i}+\beta_{16}-\beta_{27}$. Ind_Dummies $+e_{i} \quad$ (Equation 1)

\begin{tabular}{|c|c|c|c|c|c|c|c|c|c|c|c|c|}
\hline & \multicolumn{2}{|c|}{ (1) CAR_250 } & \multicolumn{2}{|c|}{ (2) CAR_500 } & \multicolumn{2}{|c|}{ (3) CAR_750 } & \multicolumn{2}{|c|}{ (4) BHAR_250 } & \multicolumn{2}{|c|}{ (5) BHAR_500 } & \multicolumn{2}{|c|}{ (6) BHAR_750 } \\
\hline & Coeff. & $\mathrm{p}$ value & Coeff. & $\mathrm{p}$ value & Coeff. & $\mathrm{p}$ value & Coeff. & $\mathrm{p}$ value & Coeff. & $\mathrm{p}$ value & Coeff. & $\mathrm{p}$ value \\
\hline Intercept & 1.411 & $0.000 * * *$ & 3.715 & $0.000 * * *$ & 4.075 & $0.000 * * *$ & 0.855 & $0.026 * * *$ & 3.171 & $0.000 * * *$ & 3.199 & $0.000 * * *$ \\
\hline $\mathrm{CM}$ & 0.031 & $0.062 *$ & 0.061 & $0.013 * *$ & 0.040 & 0.240 & 0.032 & $0.078 *$ & 0.060 & $0.055 *$ & 0.032 & 0.461 \\
\hline ab_day1_ipo & -0.145 & $0.000 * * *$ & -0.345 & $0.000 * * *$ & -0.304 & $0.000 * * *$ & -0.131 & $0.000 * * *$ & -0.370 & $0.000 * * *$ & -0.262 & $0.000 * * *$ \\
\hline netproc_equity & 0.020 & 0.147 & -0.041 & 0.823 & 0.037 & 0.102 & 0.016 & 0.271 & -0.023 & 0.296 & 0.016 & 0.581 \\
\hline sentiment & -0.124 & $0.030 * *$ & -0.234 & $0.005^{* * *}$ & -0.412 & $0.000 * * *$ & -0.083 & 0.184 & -0.319 & $0.001 * * *$ & -0.496 & $0.000 * * *$ \\
\hline hot_cold & -0.007 & $0.000 * * *$ & -0.015 & $0.000 * * *$ & 0.001 & 0.780 & -0.006 & $0.002 * * *$ & -0.016 & $0.000 * * *$ & 0.003 & 0.484 \\
\hline issuer_size & -0.098 & $0.000 * * *$ & -0.260 & $0.000 * * *$ & -0.308 & 0.000 *** & -0.058 & $0.038 * *$ & -0.204 & $0.000 * * *$ & -0.214 & $0.000 * * *$ \\
\hline car_90 & 0.050 & 0.756 & -0.079 & 0.736 & 0.142 & 0.645 & 0.020 & 0.896 & 0.067 & 0.791 & 0.100 & 0.818 \\
\hline D_002 & 0.085 & $0.056 *$ & 0.043 & 0.459 & 0.153 & $0.061 *$ & 0.102 & $0.019 * *$ & 0.116 & $0.045 * *$ & 0.233 & $0.008 * * *$ \\
\hline D_300 & 0.071 & 0.155 & 0.081 & 0.255 & 0.219 & $0.030 * *$ & 0.079 & 0.106 & 0.190 & $0.013 * *$ & 0.420 & $0.001 * * *$ \\
\hline prestige & 0.049 & 0.955 & 1.864 & 0.116 & 3.945 & $0.014 * *$ & 0.534 & 0.578 & 0.917 & 0.562 & 3.637 & 0.145 \\
\hline offer_range & -0.030 & 0.129 & -0.026 & 0.115 & -0.021 & 0.393 & -0.021 & 0.308 & -0.035 & $0.062 *$ & -0.059 & $0.036 * *$ \\
\hline state & 0.227 & $0.004 * * *$ & 0.281 & $0.006 * * *$ & 0.349 & $0.011 * *$ & 0.200 & $0.016 * *$ & 0.214 & $0.061 *$ & 0.229 & 0.175 \\
\hline legalperson & -0.058 & 0.248 & -0.051 & 0.461 & -0.016 & 0.858 & -0.055 & 0.276 & -0.082 & 0.341 & -0.049 & 0.668 \\
\hline leverage & 0.041 & 0.517 & 0.114 & 0.211 & -0.016 & 0.873 & 0.040 & 0.552 & 0.157 & 0.175 & 0.065 & 0.662 \\
\hline d_growth_ear & -0.001 & 0.983 & 0.064 & 0.155 & 0.108 & $0.073 *$ & 0.001 & 0.975 & 0.027 & 0.588 & 0.101 & 0.238 \\
\hline Ind Dummies $(=14)$ & \multicolumn{2}{|c|}{ Yes } & \multicolumn{2}{|r|}{ Yes } & \multicolumn{2}{|r|}{ Yes } & \multicolumn{2}{|c|}{ Yes } & \multicolumn{2}{|r|}{ Yes } & \multicolumn{2}{|r|}{ Yes } \\
\hline R-Squared & \multicolumn{2}{|c|}{0.104} & \multicolumn{2}{|c|}{0.257} & \multicolumn{2}{|c|}{0.225} & \multicolumn{2}{|c|}{0.065} & \multicolumn{2}{|c|}{0.179} & \multicolumn{2}{|c|}{0.155} \\
\hline $\mathrm{N}$ & \multicolumn{2}{|c|}{838} & \multicolumn{2}{|r|}{827} & \multicolumn{2}{|r|}{647} & \multicolumn{2}{|c|}{838} & \multicolumn{2}{|r|}{827} & \multicolumn{2}{|r|}{647} \\
\hline
\end{tabular}

Notes: $(* * *),(* *),(*)$ Dependent variables: Explanatory variables:
Indicates two-tailed significance at the one and five and ten percent levels, respectively.

CAR refers to cumulative abnormal returns; and BHAR to buy-and-hold returns (horizons are 250-, 500- and 750- trading days post-listing).

CM (4 if CM_Score='bb+' or ='bb'; 3 if CM_Score='bb-'; 2 if CM Score='b+'; \& 1 if CM_Score='b' or 'b-'); Netproc_Equity (Ratio of proceeds from new IPO shares to the RMB book value of assets just prior to IPO); Sentiment (Average initial return on all A-share IPOs within 30-day period prior to entity's own IPO); hot_cold (Number of IPO within the 30-day period preceding a given entity's IPO); Issuer Size (Logarithm of issuer's market capitalization (= No. of shares outstanding*final offering price); Car_90 (Cumulative abnormal return for the 90-day period leading-up to IPO (based on daily value-weighted market returns with cash dividends reinvested from all listed shares); D_002 (= 1 if the issuer lists on the Shenzhen SME market; otherwise 0); D_300 (= 1 if the issuer lists on the Shenzhen growth enterprise market; otherwise 0); Prestige (Number of IPO the leading underwriter for the current IPO has conducted since market open divided by the total number of IPOs in the market from inception); Offer_Range; (Ratio of maximum OP/minimum OP); State (Percentage of state owned shares); LegalPerson (Percentage of legal person shares); Leverage (Long term debt divided by equity); D_Growth_Ear (= 1 if listing firm has positive growth in earnings over 3 years prior to IPO, otherwise 0); and D_a to D_q (Industry dummies). See Appendix 1 for further details on variable definitions (and Appendix 2 for descriptive statistics). 
ROA $_{I}=\beta_{0}+\beta_{1} \cdot C_{i}+\beta_{2}$. ROA_b1 $1_{i}+\beta_{3}$. Netproc_Equity $+\beta_{4}$. Issuer_Size $i+\beta_{5}$. D_002 $+\beta_{6}$. D_300 ${ }_{i}+\beta_{7}$. Prestige $i$ $\beta_{9}$. State ${ }_{i}+\beta_{10}$. LegalPerson $i+\beta_{11}$. leverage ${ }_{i}+\beta_{12}$. D_Growth_Earn $i+\beta_{13}-\beta_{26}$. Ind_Dummies In $_{i}+e_{i}$ (Equation 2$)$

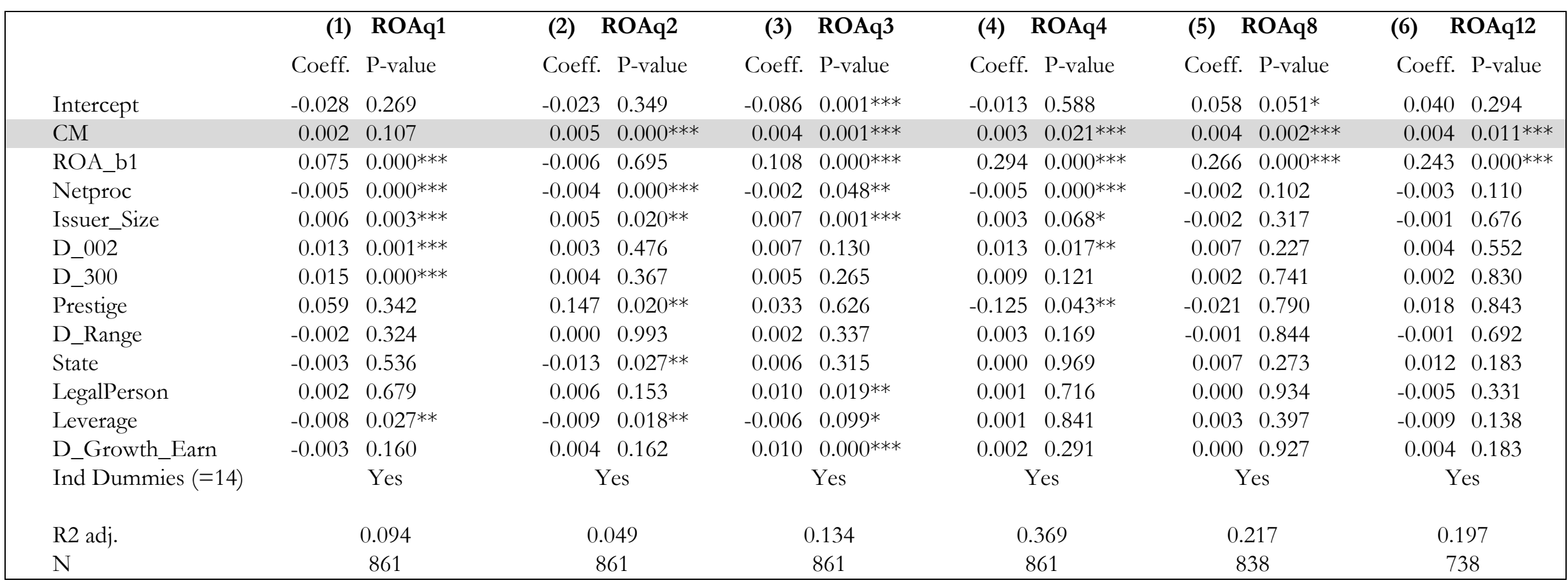

Notes: $(* *),(* *),(*)$ Dependent variable: Explanatory variables:
Indicates two-tailed significance at the one and five and ten percent levels, respectively.

ROA is the return-on-assets for IPO firm. $\mathrm{q} 1$ to $\mathrm{q} 12$ indicate the measurement period from first to the $12^{\text {th }}$ quarter.

CM $(4$ if CM_Score='bb+' or ='bb'; 3 if CM_Score='bb-'; 2 if CM Score='b+'; \& 1 if CM_Score='b' or 'b-'); ROA b1 (Return-on-assets for the IPO firm for the year-end immediately prior to IPO); Netproc (Ratio of proceeds from new IPO shares to the RMB book value of assets just prior to IPO); Issuer_Size (Logarithm of issuer's market capitalization (= No. of shares outstanding*final offering price); D_002 (= 1 if the issuer lists on the Shenzhen SME market; otherwise 0); D 300 (= 1 if the issuer lists on the Shenzhen growth enterprise market; otherwise 0); Prestige (Number of IPO the leading underwriter for the current IPO has conducted since market open divided by the total number of IPOs in the market from inception); D range $(=1$ if the issuer has an offer price range; otherwise zero); State (Percentage of state owned shares); LegalPerson (Percentage of legal person shares); Leverage (Long term debt divided by equity); D_Growth_Ear (= 1 if listing firm has positive growth in earnings over 3 years prior to IPO, otherwise 0); and D_a to D_q (Industry dummies). See Appendix 1 for further details on variable definitions (and Appendix 2 for descriptive statistics). 
$\mathrm{ROE}_{1}$

$=\quad \beta_{0}+\beta_{1} \cdot C_{i}+\beta_{2}$. ROE_b1 $+\beta_{3}$. Netproc $_{i}+\beta_{4}$. Issuer_Size $i$

$\beta_{9}$. State $_{i}+\beta_{10}$. LegalPerson $i+\beta_{11}$. leverage ${ }_{i}+\beta_{12}$. D_Growth_Earn ${ }_{i}+\beta_{13}-\beta_{26}$. Ind_Dummies ${ }_{i}+e_{i}$

(Equation 3)

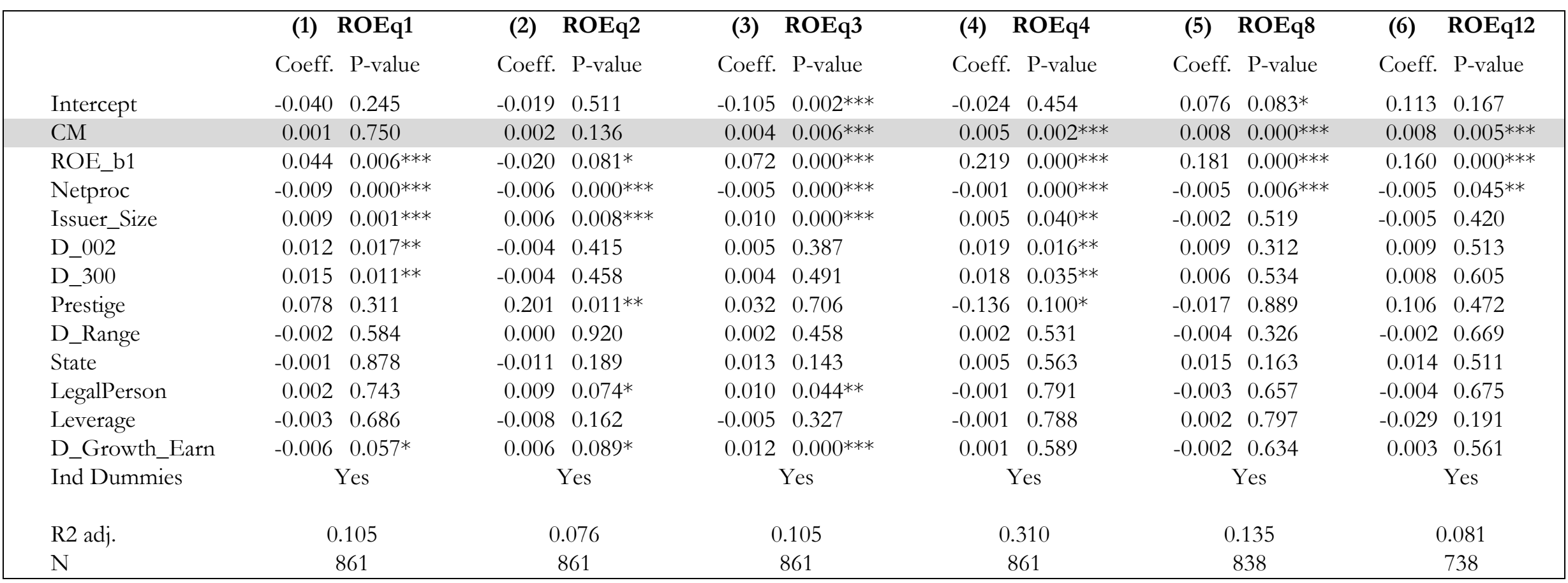

Notes: $\quad(* *),(*)$

Dependent variable:

Explanatory variables:
Indicates two-tailed significance at the one percent and five percent levels, respectively.

ROE is the return-on-equity for IPO firm. q1 to q12 indicate the measurement period from first to the $12^{\text {th }}$ quarter.

CM (4 if CM_Score='bb+' or ='bb'; 3 if CM_Score='bb-'; 2 if CM Score='b+'; \& 1 if CM_Score='b' or 'b-'); ROE_b1 (Return-on-equity for the IPO firm for the year-end immediately prior to IPO); Netproc(Ratio of proceeds from new IPO shares to the RMB book value of assets just prior to IPO); Issuer Size (Logarithm of issuer's market capitalization ( $=$ No. of shares outstanding*final offering price); D 002 (= 1 if the issuer lists on the Shenzhen SME market; otherwise 0); D_300 (= 1 if the issuer lists on the Shenzhen growth enterprise market; otherwise 0); Prestige (Number of IPO the leading underwriter for the current IPO has conducted since market open divided by the total number of IPOs in the market from inception); D range $(=1$ if the issuer has an offer price range; otherwise zero); State (Percentage of state owned shares); LegalPerson (Percentage of legal person shares); Leverage (Long term debt divided by equity); D_Growth_Ear (= 1 if listing firm has positive growth in earnings over 3 years prior to IPO, otherwise 0); and D_a to D_q (Industry dummies). See Appendix 1 for further details on variable definitions (and Appendix 2 for descriptive statistics). 


\begin{tabular}{|c|c|c|c|c|c|c|c|c|c|c|c|c|}
\hline & \multicolumn{2}{|c|}{ (1) CAR_250 } & \multicolumn{2}{|c|}{ (2) CAR_500 } & \multicolumn{2}{|c|}{ (3) CAR_750 } & \multicolumn{2}{|c|}{ (4) BHAR_250 } & \multicolumn{2}{|c|}{ (5) BHAR_500 } & \multicolumn{2}{|c|}{ (6) BHAR_750 } \\
\hline & Coeff. & $\mathrm{p}$ value & Coeff. & $\mathrm{p}$ value & Coeff. & $\mathrm{p}$ value & Coeff. & $\mathrm{p}$ value & Coeff. & $\mathrm{p}$ value & Coeff. & $\mathrm{p}$ value \\
\hline Intercept & 1.421 & $0.000 * * *$ & 3.733 & $0.000 * * *$ & 4.092 & $0.000 * * *$ & 0.867 & $0.024 * *$ & 3.192 & $0.000 * * *$ & 3.212 & $0.000 * * *$ \\
\hline CM1 & 0.041 & $0.066 *$ & 0.072 & $0.022 * *$ & 0.033 & 0.423 & 0.044 & $0.062 *$ & 0.083 & $0.025 * *$ & 0.044 & 0.354 \\
\hline ab_day1_ipo & -0.144 & $0.000 * * *$ & -0.343 & $0.000 * * *$ & -0.302 & $0.000 * * *$ & -0.131 & $0.000 * * *$ & -0.369 & $0.000 * * *$ & -0.262 & $0.000 * * *$ \\
\hline netproc_equity & 202.705 & 0.135 & -28.807 & 0.874 & 385.069 & $0.089 *$ & 162.323 & 0.257 & -227.773 & 0.311 & 166.162 & 0.572 \\
\hline sentiment & -0.126 & $0.028 * *$ & -0.238 & $0.005 * * *$ & -0.417 & $0.000 * * *$ & -0.085 & 0.174 & -0.322 & $0.001 * * *$ & -0.497 & $0.000 * * *$ \\
\hline hot_cold & -0.007 & $0.000 * * *$ & -0.015 & $0.000 * * *$ & 0.001 & 0.781 & -0.006 & $0.002 * * *$ & -0.016 & $0.000 * * *$ & 0.003 & 0.483 \\
\hline issuer_size & -0.098 & $0.000 * * *$ & -0.259 & $0.000 * * *$ & -0.306 & $0.000 * * *$ & -0.058 & $0.036 * *$ & -0.205 & $0.000 * * *$ & -0.215 & $0.000 * * *$ \\
\hline car_90 & 0.053 & 0.742 & -0.072 & 0.757 & 0.149 & 0.630 & 0.022 & 0.885 & 0.071 & 0.779 & 0.103 & 0.813 \\
\hline prestige & 0.054 & 0.951 & 1.890 & 0.111 & 3.988 & $0.013 * *$ & 0.532 & 0.579 & 0.916 & 0.563 & 3.641 & 0.142 \\
\hline offer_range & -0.030 & 0.126 & -0.027 & 0.107 & -0.022 & 0.376 & -0.021 & 0.302 & -0.035 & $0.058 *$ & -0.059 & $0.035 * *$ \\
\hline state & 0.232 & $0.003 * * *$ & 0.291 & $0.005 * * *$ & 0.356 & $0.010 * * *$ & 0.204 & $0.014 * *$ & 0.223 & $0.053 *$ & 0.232 & 0.171 \\
\hline legalperson & -0.058 & 0.249 & -0.052 & 0.452 & -0.019 & 0.833 & -0.055 & 0.282 & -0.081 & 0.344 & -0.048 & 0.678 \\
\hline leverage & 0.035 & 0.578 & 0.097 & 0.271 & -0.039 & 0.680 & 0.035 & 0.593 & 0.148 & 0.200 & 0.060 & 0.667 \\
\hline d_growth_ear & 0.000 & 0.995 & 0.065 & 0.153 & 0.107 & $0.079 *$ & 0.002 & 0.958 & 0.029 & 0.572 & 0.102 & 0.236 \\
\hline Ind Dummies $(=14)$ & \multicolumn{2}{|r|}{ Yes } & \multicolumn{2}{|c|}{ Yes } & \multicolumn{2}{|c|}{ Yes } & \multicolumn{2}{|c|}{ Yes } & \multicolumn{2}{|c|}{ Yes } & \multicolumn{2}{|c|}{ Yes } \\
\hline R-squared & \multicolumn{2}{|r|}{0.104} & \multicolumn{2}{|c|}{0.257} & \multicolumn{2}{|c|}{0.224} & \multicolumn{2}{|c|}{0.066} & \multicolumn{2}{|c|}{0.180} & \multicolumn{2}{|c|}{0.155} \\
\hline $\mathrm{N}$ & \multicolumn{2}{|r|}{838} & \multicolumn{2}{|c|}{827} & \multicolumn{2}{|c|}{647} & \multicolumn{2}{|c|}{838} & \multicolumn{2}{|c|}{827} & \multicolumn{2}{|c|}{647} \\
\hline
\end{tabular}

Notes: $(* * *),(* *),(*)$

Dependent variables:

Explanatory variables:
Indicates two-tailed significance at the one, five and ten percent levels, respectively.

CAR refers to cumulative abnormal returns (= sum of 90 successive market-adjusted close-to-close returns); and

BHAR to buy-and-hold returns (horizons are 250-, 500- and 750- trading days post-listing).

CM1 (3 if CM_Score_1 ='bb+' or ='bb'; 2 if = bb-; and 1 if ='b+', 'b' or 'b-'; ab_day1_ipo (Initial return [=(closing price-FOP/FOP)-(market return on first dav)]); Netproc (Ratio of proceeds from new IPO shares to the RMB book value of assets just prior to IPO); Sentiment (Average initial return on all A-share IPOs within 30-day period prior to entity's own IPO); hot_cold (Number of IPO within the 30-day period preceding a given entity's IPO); Issuer_Size (Logarithm of issuer's market capitalization (= No. of shares outstanding*final offering price); Car_90 (Cumulative abnormal return for the 90-day period leading-up to IPO (based on daily value-weighted market returns with cash dividends reinvested from all listed shares); Prestige (Number of IPO the leading underwriter for the current IPO has conducted since market open divided by the total number of IPOs in the market from inception); offer_range (ratio of maximum OP/minimum OP); State (Percentage of state owned shares); LegalPerson (Percentage of legal person shares); Leverage (Long term debt divided by equity); D_Growth_Ear (= 1 if listing firm has positive growth in earnings over 3 years prior to IPO, otherwise 0); and D_a to D_q (Industry dummies). See Appendix 1 for further details on variable definitions (and Appendix 2 for descriptive statistics). 


\begin{tabular}{|c|c|c|c|c|c|c|c|c|c|c|c|c|}
\hline & (1) & ROAq1 & (2) & ROAq2 & (3) & ROAq3 & (4) & ROAq4 & (5) & ROAq8 & (6) & ROAq12 \\
\hline & Coeff. & $\mathrm{P}$ value & Coeff. & $\mathrm{P}$ value & Coeff. & $\mathrm{P}$ value & Coeff. & $\mathrm{P}$ value & Coeff. & $\mathrm{P}$ value & Coeff. & $P$ value \\
\hline Intercept & -0.027 & 0.285 & -0.021 & 0.390 & -0.085 & $0.001 * * *$ & -0.011 & 0.628 & 0.060 & $0.043 * *$ & 0.043 & 0.268 \\
\hline CM1 & 0.002 & 0.288 & 0.006 & $0.000 * * *$ & 0.005 & $0.005^{* * *}$ & 0.002 & 0.137 & 0.005 & $0.017 * *$ & 0.004 & $0.089 *$ \\
\hline ROA_b1 & 0.077 & $0.000 * * *$ & -0.005 & 0.720 & 0.111 & $0.000^{* * *}$ & 0.297 & $0.000 * * *$ & 0.269 & $0.000 * * *$ & 0.247 & $0.000^{* * *}$ \\
\hline netproc_equity & -0.005 & $0.000 * * *$ & -0.003 & $0.000 * * *$ & -0.002 & $0.054^{*}$ & -0.005 & $0.000 * * *$ & -0.002 & 0.107 & -0.003 & 0.113 \\
\hline issuer_size & 0.006 & $0.002^{* * *}$ & 0.005 & $0.022 * *$ & 0.007 & $0.001 * * *$ & 0.003 & $0.058 *$ & -0.002 & 0.332 & -0.001 & 0.703 \\
\hline d_002 & 0.013 & $0.001 * * *$ & 0.003 & 0.444 & 0.007 & 0.122 & 0.013 & $0.016 * *$ & 0.007 & 0.219 & 0.004 & 0.546 \\
\hline d_300 & 0.015 & $0.000^{* * *}$ & 0.004 & 0.328 & 0.006 & 0.234 & 0.009 & 0.108 & 0.003 & 0.701 & 0.002 & 0.801 \\
\hline prestige & 0.060 & 0.331 & 0.148 & $0.018 * *$ & 0.035 & 0.601 & -0.123 & $0.047 * *$ & -0.019 & 0.809 & 0.021 & 0.814 \\
\hline d_range & -0.002 & 0.313 & 0.000 & 0.959 & 0.002 & 0.363 & 0.003 & 0.182 & -0.001 & 0.811 & -0.001 & 0.665 \\
\hline state & -0.003 & 0.590 & -0.012 & $0.037 * *$ & 0.007 & 0.250 & 0.000 & 0.931 & 0.008 & 0.221 & 0.013 & 0.157 \\
\hline legalperson & 0.001 & 0.704 & 0.006 & 0.152 & 0.010 & $0.021 * *$ & 0.001 & 0.760 & 0.000 & 0.962 & -0.005 & 0.314 \\
\hline leverage & -0.008 & $0.015^{* *}$ & -0.010 & $0.010^{* *}$ & -0.008 & $0.044 * *$ & -0.001 & 0.880 & 0.002 & 0.630 & -0.011 & $0.097 *$ \\
\hline d_growth_ear & -0.003 & 0.157 & 0.004 & 0.152 & 0.010 & $0.000^{* * *}$ & 0.002 & 0.303 & 0.000 & 0.926 & 0.004 & 0.188 \\
\hline Ind Dummies $(=14)$ & & Yes & & Yes & & Yes & & Yes & & Yes & & Yes \\
\hline R-Squared & & 0.093 & & 0.050 & & 0.132 & & 0.367 & & 0.215 & & 0.195 \\
\hline $\mathrm{N}$ & & 861 & & 861 & & 861 & & 861 & & 838 & & 738 \\
\hline
\end{tabular}

Notes: $(* * *),(* *),(*)$ Dependent variable: Explanatory variables:
Indicates two-tailed significance at the one, five and ten percent levels, respectively.

ROA (Return-on-assets for IPO firm).

CM1 3 if CM1 ='bb+' or ='bb'; 2 if = bb-; and 1 if ='b+', 'b' or 'b-'; ROE b1 (Return-on-equity for the IPO firm for the year-end immediately prior to IPO); Netproc(Ratio of proceeds from new IPO shares to the RMB book value of assets just prior to IPO); Issuer_Size (Logarithm of issuer's market capitalization (= No. of shares outstanding*final offering price); D_002 (= 1 if the issuer lists on the Shenzhen SME market; otherwise 0); D_300 (= 1 if the issuer lists on the Shenzhen growth enterprise market; otherwise 0); Prestige (Number of IPO the leading underwriter for the current IPO has conducted since market open divided by the total number of IPOs in the market from inception); D_range (= 1 if the issuer has an offer price range; otherwise zero); State (Percentage of state owned shares); LegalPerson (Percentage of legal person shares); Leverage (Long term debt divided by equity); D_Growth_Ear (= 1 if listing firm has positive earnings growth over 3 years prior to IPO, otherwise 0 ); and $\mathbf{D} \_a$ to D_q (Industry dummies).

See Appendix 1 for further details on variable definitions (and Appendix 2 for descriptive statistics). 


\begin{tabular}{|c|c|c|c|c|c|c|c|c|c|c|c|c|}
\hline \multirow[b]{3}{*}{ Intercept } & \multicolumn{2}{|c|}{ ROEq1 } & \multicolumn{2}{|c|}{ ROEq2 } & \multicolumn{2}{|c|}{ (3) ROEq3 } & \multicolumn{2}{|c|}{ (4) $\mathrm{ROEq4}$} & \multicolumn{2}{|r|}{ ROEq8 } & \multicolumn{2}{|c|}{ (6) ROEq12 } \\
\hline & Coeff. & $\mathrm{P}$ value & Coeff. & $\mathrm{P}$ value & Coeff. & $\mathrm{P}$ value & Coeff. & $\mathrm{P}$ value & Coeff. & $\mathrm{P}$ value & Coeff. & $\mathrm{P}$ value \\
\hline & -0.040 & 0.247 & -0.018 & 0.532 & -0.103 & $0.002^{* * *}$ & -0.022 & 0.495 & 0.079 & $0.070^{*}$ & 0.117 & 0.152 \\
\hline CM1 & 0.001 & 0.741 & 0.004 & $0.030 * *$ & 0.005 & $0.012^{* *}$ & 0.005 & $0.009 * * *$ & 0.009 & $0.001 * * *$ & 0.009 & $0.054 *$ \\
\hline ROE_b1 & 0.044 & $0.006^{* * *}$ & -0.021 & $0.066^{*}$ & 0.073 & $0.000^{* * *}$ & 0.220 & $0.000 * * *$ & 0.183 & $0.000^{* * *}$ & 0.162 & $0.000 * * *$ \\
\hline netproc_equity & -0.009 & $0.000^{* * *}$ & -0.006 & $0.000^{* * *}$ & -0.005 & $0.000^{* * *}$ & -0.010 & $0.000 * * *$ & -0.005 & $0.007 * * *$ & -0.004 & $0.049 * *$ \\
\hline issuer_size & 0.009 & $0.001 * * *$ & 0.006 & $0.010 * * *$ & 0.010 & $0.000^{* * *}$ & 0.005 & $0.037 * *$ & -0.002 & 0.522 & -0.005 & 0.435 \\
\hline prestige & 0.078 & 0.311 & 0.199 & $0.011^{* *}$ & 0.034 & 0.688 & -0.133 & 0.107 & -0.014 & 0.908 & 0.113 & 0.441 \\
\hline d_range & -0.002 & 0.581 & 0.000 & 0.933 & 0.002 & 0.480 & 0.002 & 0.560 & -0.004 & 0.304 & -0.002 & 0.648 \\
\hline state & -0.001 & 0.887 & -0.011 & 0.196 & 0.013 & 0.119 & 0.006 & 0.482 & 0.016 & 0.127 & 0.015 & 0.468 \\
\hline legalperson & 0.002 & 0.741 & 0.009 & $0.065^{*}$ & 0.010 & $0.045^{* *}$ & -0.001 & 0.760 & -0.003 & 0.635 & -0.004 & 0.655 \\
\hline leverage & -0.003 & 0.671 & -0.008 & 0.185 & -0.006 & 0.218 & -0.003 & 0.552 & -0.001 & 0.938 & -0.032 & 0.165 \\
\hline d_growth_ear & -0.006 & $0.058^{*}$ & 0.006 & $0.080^{*}$ & 0.012 & $0.000^{* * *}$ & 0.001 & 0.596 & -0.002 & 0.644 & 0.003 & 0.562 \\
\hline Ind Dummies $(=14)$ & \multicolumn{2}{|r|}{ Yes } & \multicolumn{2}{|r|}{ Yes } & \multicolumn{2}{|r|}{ Yes } & \multicolumn{2}{|r|}{ Yes } & \multicolumn{2}{|r|}{ Yes } & \multicolumn{2}{|r|}{ Yes } \\
\hline $\mathrm{R}$ squared & \multicolumn{2}{|c|}{0.105} & \multicolumn{2}{|c|}{0.079} & \multicolumn{2}{|r|}{0.104} & \multicolumn{2}{|c|}{0.309} & \multicolumn{2}{|c|}{0.134} & \multicolumn{2}{|c|}{0.078} \\
\hline $\mathrm{N}$ & \multicolumn{2}{|r|}{861} & \multicolumn{2}{|r|}{861} & \multicolumn{2}{|r|}{861} & \multicolumn{2}{|r|}{861} & \multicolumn{2}{|r|}{838} & \multicolumn{2}{|r|}{738} \\
\hline
\end{tabular}

Notes: $(* * *),(* *),(*)$ Dependent variable:

Explanatory variables:
Indicates two-tailed significance at the one, five and ten percent levels, respectively. ROE (Return-on-equity for IPO firm).

CM1 (3 if CM_Score ='bb+' or ='bb'; 2 if = bb-; and 1 if ='b+', 'b' or 'b-'; ROE_b1 (Return-on-equity for the IPO firm for the year-end immediately prior to IPO); Netproc(Ratio of proceeds from new IPO shares to the RMB book value of assets just prior to IPO); Issuer_Size (Logarithm of issuer's market capitalization (= No. of shares outstanding*final offering price); D 002 (= 1 if the issuer lists on the Shenzhen SME market; otherwise 0); D_300 (= 1 if the issuer lists on the Shenzhen growth enterprise market; otherwise 0); Prestige (Number of IPO the leading underwriter for the current IPO has conducted since market open divided by the total number of IPOs in the market from inception); D_range (= 1 if the issuer has an offer price range; otherwise zero); State (Percentage of state owned shares); LegalPerson (Percentage of legal person shares); Leverage (Long term debt divided by equity); D_Growth_Ear (= 1 if listing firm has positive growth in earnings over 3 years prior to IPO, otherwise 0); and $\mathbf{D} \_a$ to $\mathbf{D} \_\mathbf{q}$ (Industry dummies).

See Appendix 1 for further details on variable definitions (and Appendix 2 for descriptive statistics). 
PE_postIPO: Price to diluted earnings ratio post IPO

Initial Underpricing (FUNDret): (Intrinsic value/IPO price)-1

Intrinsic value is calculated as the value of the company imputed by the industry $\mathrm{PE}$ ratio.

Market Reaction (MARKret)

Intrinsic value $=$ Earnings before IPO*median industry PE ratio

[(First day closing price/intrinsic value)-1] - Market return during the same day.

BHAR_n: Abnormal buy-and-hold return from the second day after IPO to $n$ trading days, as adjusted for contemporaneous market return.

CAR_n: $\quad$ Cumulative abnormal return from the second day after IPO to $n$ trading days.

CM

If CM_Score='bb+' or CM_Score='bb'

then score $=4$.

If CM_Score='bb-'

If CM_Score='b+'

If CM_Score='b' or CM_Score='b-'

then score $=3$.

then score $=2$.

then score $=1$.

\section{CM1}

If CM_Score='bb+' or CM_Score='bb' then score=3.

If CM_Score='bb-' then score $=2$.

If CM_Score='b+', 'b' or 'b-' then score $=1$.

Ab_Day1_IPO Abnormal return of the first day after IPO.

Netproc_equity: Ratio of proceeds from new IPO shares to the RMB book value of assets just prior to IPO.

Sentiment: Average initial return on all A-share IPOs within 30-day period prior to entity's own IPO.

Hot_Cold: $\quad$ Number of IPO within the 30-day period preceding a given entity's IPO.

Car_90: Cumulative abnormal return for the 90-day period leading-up to IPO (based on daily value-weighted market returns with cash dividends reinvested from all listed shares).

Issuer_Size: Logarithm of issuer's market capitalization (= No. of shares outstanding*final offer price).

D_002: $\quad$ Equal to 1 if the issuer lists on the Shenzhen SME market; otherwise 0;

D_300: $\quad$ Equal to 1 if the issuer lists on the Shenzhen ChiNext market; otherwise 0;

Prestige: Number of IPO the leading underwriter for the current IPO has conducted since market open divided by the total number of IPOs in the market from inception.

D_range: Equal to 1 if the issuer has an offer price range; otherwise zero.

State: Percentage of state owned shares.

LegalPerson: Percentage of legal person shares.

Leverage: Long term debt divided by equity.

D_Growth_Ear

$=1$ if listing firm has positive growth in earnings over 3 years prior to IPO, otherwise 0 .

D_a to D_q: industry dummies (17 industry sector dummies but only 14 feature: industry codes $\mathrm{j}, \mathrm{k}$, $\mathrm{p}$ have no stocks in our sample).

ROA_b1 (or ROE_b1)

Return-on-assets (Return-on-equity) for IPO firm for year-end immediately prior to IPO. 


\begin{tabular}{|c|c|c|c|c|c|c|}
\hline & Mean & Median & Max & Min & Std & $\mathbf{N}$ \\
\hline PE_postIPO & 49.42 & 46.92 & 150.82 & 7.17 & 20.55 & 861 \\
\hline Initial Underpricing (FUNDret) & 0.49 & 0.26 & 29.51 & -0.82 & 1.53 & 861 \\
\hline Market Reaction (MARKret) & 0.32 & 0 & 7.52 & -0.97 & 1.01 & 861 \\
\hline BHAR_250 & -0.05 & -0.14 & 4.1 & -0.7 & 0.37 & 838 \\
\hline BHAR_500 & 0.08 & -0.1 & 7.44 & -0.66 & 0.66 & 827 \\
\hline BHAR_750 & 0.2 & -0.04 & 6.86 & -0.74 & 0.84 & 647 \\
\hline Ab_Ret_250 & -0.04 & -0.08 & 2.14 & -1 & 0.35 & 838 \\
\hline Ab_Ret_500 & 0.08 & 0.02 & 2.38 & -1.21 & 0.53 & 827 \\
\hline Ab_Ret_750 & 0.24 & 0.17 & 2.67 & -1.4 & 0.62 & 647 \\
\hline Score & 2.49 & 3 & 4 & 1 & 0.76 & 861 \\
\hline Score_1 & 1.6 & 2 & 3 & 1 & 0.58 & 861 \\
\hline Netproc_Equity & 1.37 & 1.14 & 6.41 & 0.08 & 0.95 & 861 \\
\hline Ab_Day1_IPO & 0.35 & 0.27 & 2.75 & -0.27 & 0.39 & 861 \\
\hline Sentiment & 0.35 & 0.32 & 1.18 & -0.02 & 0.24 & 861 \\
\hline Hot_Cold & 22.58 & 24 & 41 & 1 & 8.17 & 861 \\
\hline Issuer_Size & 11.17 & 11.08 & 14.14 & 9.75 & 0.66 & 861 \\
\hline Car_90 & -0.01 & -0.02 & 0.2 & -0.21 & 0.07 & 861 \\
\hline D_002 & 0.49 & 0 & 1 & 0 & 0.5 & 861 \\
\hline D_300 & 0.42 & 0 & 1 & 0 & 0.49 & 861 \\
\hline Prestige & 0.02 & 0.01 & 0.05 & 0 & 0.01 & 861 \\
\hline Offer_Range & 1.88 & 1.95 & 9.8 & 1 & 0.87 & 861 \\
\hline D_Range & 0.72 & 1 & 1 & 0 & 0.45 & 861 \\
\hline State & 0.07 & 0 & 0.84 & 0 & 0.17 & 861 \\
\hline Legalperson & 0.24 & 0.15 & 0.9 & 0 & 0.24 & 861 \\
\hline Leverage & 0.11 & 0 & 2.91 & 0 & 0.22 & 861 \\
\hline D_Growth_Ear & 0.87 & 1 & 1 & 0 & 0.34 & 861 \\
\hline ROA_b1 & 0.09 & 0.08 & 0.4 & -0.02 & 0.06 & 861 \\
\hline ROE_b1 & 0.16 & 0.15 & 0.57 & -0.03 & 0.1 & 861 \\
\hline
\end{tabular}

